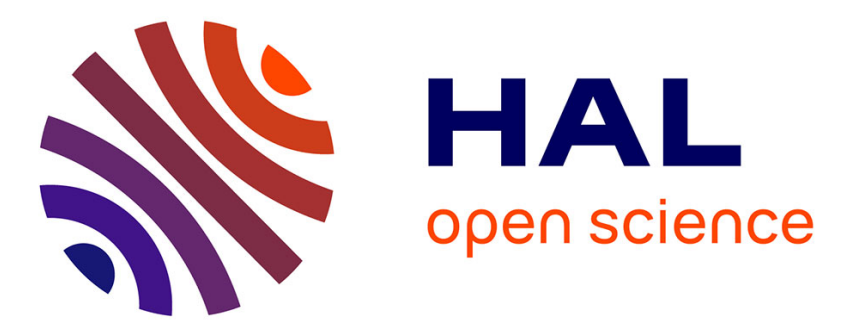

\title{
Children of War: In-Utero Stress and Child Health in Iraq
}

Sulin Sardoschau

\section{To cite this version:}

Sulin Sardoschau. Children of War: In-Utero Stress and Child Health in Iraq. 2019. halshs-02383137

\section{HAL Id: halshs-02383137 \\ https://shs.hal.science/halshs-02383137}

Preprint submitted on 27 Nov 2019

HAL is a multi-disciplinary open access archive for the deposit and dissemination of scientific research documents, whether they are published or not. The documents may come from teaching and research institutions in France or abroad, or from public or private research centers.
L'archive ouverte pluridisciplinaire HAL, est destinée au dépôt et à la diffusion de documents scientifiques de niveau recherche, publiés ou non, émanant des établissements d'enseignement et de recherche français ou étrangers, des laboratoires publics ou privés. 


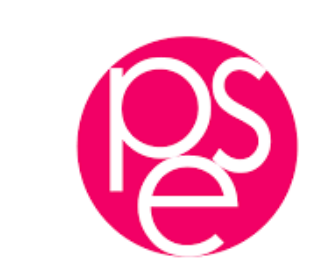

PARIS SCHOOL OF ECONOMICS
ECOLE D'ECONOMIE DE PARIS

WORKING PAPER N 2019 - 62

Children of War: In-Utero Stress and Child Health in Iraq

Sulin Sardoschau

JEL Codes: I12 , J13 , 015

Keywords: stress, violence, health, Iraq

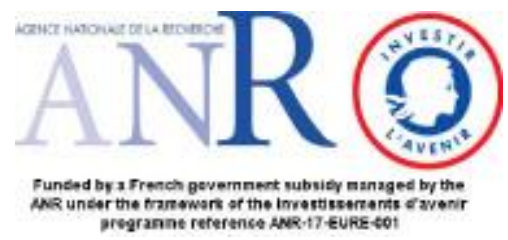




\title{
Children of War: In-Utero Stress and Child Health in Iraq
}

\author{
Sulin Sardoschau*
}

September, 2019

\begin{abstract}
This paper combines detailed household-level data on child health with geo-coded incidences of violence in Iraq to estimate the impact of in-utero exposure to violence on biometric, behavioral and cognitive outcomes of children. Rich data on severity (duration and casualties), type (bombings, explosions, gunfire etc.), and perpetrators of violence (coalition, insurgent, or sectarian) on the district level allow me to discriminate between two possible mechanisms: damages to the infrastructure versus violence-induced pre-natal stress for mothers. Comparing siblings within the same household, I find that one single violent incidence during pregnancy significantly increases the risk of stuntedness, malnutrition and weakens major cognitive and behavioral skills. While the type of violence does not seem to play a major role, the perpetrator of violence seems to matter. Violent acts that explicitly target the civilian population, even if they have little effect on the general infrastructure, appear to be the driver behind the effect.
\end{abstract}

Keywords: stress, violence, health, Iraq

JEL classification: I12, J13, O15

\footnotetext{
*I would like to that participants of the PSE Development Seminar, the AFSE annual meeting, as well as helpful comments by Karen Macours, Sylvie Lambert, Toman Barsbai, Thierry Verdier, Rajshri Jayaraman, Hillel Rapoport and Emmanuelle Auriol.

* Paris School of Economics and Université de Paris 1 Panthéon Sorbonne, contact: sulin.sardoschau@psemail.eu
} 


\section{Introduction}

The recent history of Iraq has been dominated by war. The US invasion of Iraq and the toppling of the Hussein dictatorship in 2003 was followed by an outpouring of insurgent violence that continues to this day. The Iraq Body Count Project estimates the total number of fatalities between 2003 and 2018 to almost 200,000 , which is 20 times the number of fatalities in the history of the Israeli-Palestinian conflict ${ }^{1}$. Aside from its devastating effects on Iraq's economy, the continuous exposure to conflict has also taken a toll on the mental health of the Iraqi population. According to the 2007 Iraq Mental Health Survey, $16.5 \%$ of the 32,000 respondents reported symptoms of severe mental disorder; this number is even higher, about $20 \%$, for women ${ }^{2}$. About $5 \%$ of women in the Iraq Mental Health survey report symptoms of PTSD. Health professionals propose that among all mental disorders, post-traumatic stress disorder (PTSD) is one of the main drivers through which parents transmit adverse effects to their children during war-times (Devakumar et al., 2014; Murthy \& Lakshminarayana, 2006). Particularly intrauterine exposure to stress can cause major impediments to child development. Medical research shows that prenatal stress (especially in early stages of pregnancy) increases levels of Corticotrophin Releasing Hormone (CRH), which regulates fetal maturation and thus increases the risk of adverse birth outcomes (Beydoun \& Saftlas, 2008; László et al., 2014; Glynn et al., 2001).

It is now well-established in the literature that prenatal events have life-long consequences (Almond \& Currie, 2011; Almond et al., 2017). The so-called "fetal origins" hypothesis (FOH) was first subject of interest for physicians, particularly David J. Barker in the 1990s, and has expanded to the economics literature in recent years, where it has become a main pillar in the theory of human capital accumulation. The FOH in economics has been analyzed in six major contexts: nutritional shocks, infectious diseases, exposure to pollution, weather and climate change, use of alcohol and tobacco, as well as maternal stress. Several papers look at mild nutritional shocks in-utero induced by pregnancy during ramadan (Majid, 2015; Van Ewijk, 2011; Almond \& Mazumder, 2011) and show that they have a substantial effect on various outcomes, such as income, education (attainment and test scores), or mental disability. Similarly, in-utero exposure to water borne diseases or influenza have important long-run consequences. For instance Beach et al. (2016) look at water quality in the United States and find that moving from the top of the typhoid distribution to eradication would increase educational attainment in surviving children by $1 / 3$ of a year and increase earnings by $4 \%$. Beyond nutritional or infectious components that negatively effect child health and long-run human capital accumulation, there are also environmental factors that severely impact the intrauterine well being of children. Isen et al. (2017) exploit the Clean Air Act of 1970 as a natural experiment to estimate the effect of exposure to pollution during pregnancy on employment probability and earnings in adulthood. They use a regression discontinuity design to compare counties that were just above the maximum pollution threshold and had to implement pollution reduction measures to those that were just below the threshold. The authors find that less exposure to pollution during pregnancy increases

\footnotetext{
${ }^{1}$ Statistics from B'Tselem, an Israeli human rights organization, are used because they are largely considered to have comprehensive and nonpartisan data. Find access here: https://israelipalestinian.procon.org/view.resource.php?resourceID=000639

${ }^{2}$ World Health Organization and Ministry of Health, Iraq Mental Health Survey 2007. Find access here: http://apps.who.int/iris/handle/10665/116610
} 
earnings by over 4,000 USD. Almond et al. (2009) use exposure to Chernobyl fallout in Sweden as a natural experiment inducing variation in cognitive ability. The authors find that students born in regions of Sweden with higher fallout performed worse in secondary school, in mathematics in particular, which holds (and is even accentuated) using household fixed effects. Many of the other environmental shocks, such as rainfall, extreme heat or droughts are found to have a large impact on various outcomes right after birth (such as birth weight and height), in the medium-run (school attendance and attainment) and the long-run (employment, income or mental health). However, there are various mechanisms through which these environmental shocks can operate, such as shocks to income or behavioral responses (Ngo \& Horton, 2016; Andalón et al., 2016; Dercon \& Porter, 2014; Banerjee et al., 2010) . Shah \& Steinberg (2017) show that droughts actually increase educational attainment since children switch from agricultural work to school instead. In the context of Ghana, Adhvaryu et al. (2014) show that a one standard deviation rise in the cocoa price in early life decreases the likelihood of severe mental distress in adulthood by 3 percentage points, proposing maternal nutrition as one of the main channels. When it comes to substance abuse of mothers, many authors use policy changes in access to tobacco and alcohol to measure the long-run effects on children. Nilsson (2017) looks at how a Swedish policy that sharply increased alcohol availability during 8.5 months affected the labor productivity of those exposed to it in utero. He finds that cohorts affected in utero early in pregnancy had $24 \%$ lower earnings at age 30, as well as lower cognitive, non-cognitive, and educational outcomes.

Lastly, there is a prominent body of literature that tries to assess the effects of prenatal maternal stress on child health and long-run outcomes (Adhvaryu et al., 2014; Cunha et al., 2010; Almond, 2006). While it is well established in the medical literature that stress and the associated bio-chemical response is harmful to children, it is difficult to disentangle stress from other components in larger population studies. There are no large scale longitudinal data sets that measure CRH or Cortisol levels in mothers explicitly. Usually, a direct test of stress is therefore impossible. One exception is Aizer et al. (2016) who collect data from perinatal care centers in the 1960s and show that infants exposed to higher cortisol levels during pregnancy have up to 1 year less school at age 7 than their siblings. Since this type of data is typically unavailable, economists refute to reduced form estimations that use an exogenous event that reasonably affects stress in mothers to estimate the impact of intrauterine stress on long-run outcomes. Currie \& Rossin-Slater (2013) look at pregnant women in Texas who lived in the announced potential path of major hurricanes but ended up not being affected by it. Looking at birth outcomes, the authors find that women affected women are more likely to give birth to children with an abnormality. Duncan et al. (2016) exploit the in-utero exposure to the Super Bowl to estimate the stress-channel. The authors argue that this important sports event in the United States elicits intense emotions among viewers depending on whether they local team makes it to the final. However, their data does not allow for including a mother or household fixed effect, which makes selection into exposure to the Super Bowl along unobservables (which simultaneously affect child birth weight) likely. Persson \& Rossin-Slater (2018) analyze how in utero exposure to maternal stress from family ruptures affects later mental health. They show that exposure to the death of a maternal relative increases take-up of ADHD medications during childhood and anti-anxiety and depression medications in adulthood. 
In the context of conflict and violence, it is difficult to disentangle the effect of stress from other mechanisms. There are usually various confounding factors that play into the inter-generational transmission of war. The literature on in-utero exposure to conflict and child health outcomes has been studied in two main contexts, either in one of brief and extreme episodes of violence, such as the attacks on the World Trade Center in September 2001, landmine explosions or the al-Aqsa Intifada (Brown, 2015; Mansour \& Rees, 2012; Eccleston, 2011; Camacho, 2008) or systematic "day to day" crime-related exposure to violence in Latin and South America (Nasir et al., 2016; Koppensteiner \& Manacorda, 2016; Brown, 2015; Torche $\&$ Villarreal, 2014). On the one hand, large scale incidences of violence are difficult to disentangle from other variables that may simultaneously influence child health outcomes, such as deterioration of health infrastructure or behavioral responses of parents. On the other hand, it is hard to argue that lower scale, more regular, crime-related incidences are exogenous or unpredictable. Therefore, a major concern in these studies is the selection of households into crime-ridden neighborhoods along unobservable characteristics ${ }^{3}$. Mansour \& Rees (2012) is the study that is most closely related to this analysis. The authors draw from the 2004 Palestinian Demographic and Health Survey, which was conducted approximately 4 years after the start of the al-Aqsa Intifada, and find that an additional conflict-related fatality 9 to 6 months before birth is associated with with a modest increase in the probability of having a child who weighed less than 2500 g. The al-Aqsa Intifada, or the so-called Second Intifada, started in September 2000 with the controversial visit of Ariel Sharon to the al-Aqsa Mosque, marking the beginning of a 5 year violent confrontation between Israel and Palestine that cost more than 4000 lives. The authors argue that despite the cyclicality of violence in this conflict (regular alternations between intense and calmer periods of violence), Palestinians were not able to predict and consequently adjust to attacks by Israel. They exploit this arguably exogenous exposure to conflict to the birth weight of children. WhileMansour \& Rees (2012) propose in-utero exposure to stress as one potential channel through which conflict can affect child health outcomes, they also acknowledge that there are various other mechanisms that may confound their estimate. For instance, incursions, check points, curfews and road blocks could have limited access to prenatal care or compelled Palestinian women to walk when under normal circumstances they would have taken public transportation, which would include lack of prenatal care and physical exertion as potential drivers of their results.

Overall, the evidence emphasizes the importance of the inter-generational transmission of deprivation, mental health and poverty. War does not only affect the current generation but all the generations to come, not only through mental health and stress but through all types of war-related deprivation. In the context of the Korean war, Lee (2014) shows that health outcomes as well as cognitive skills of the subjects of the 1951 birth cohort, who were in utero during the worst time of the war, were severely affected 40 and 50 years later. The destruction of school infrastructure during World War II was a major impediment to educational attainment, labor market status and health many years later, as Akbulut-Yuksel (2014) shows in the case of Germany. Despite the long-lasting and severe conflict that has shaken the Middle East in the last decades, there is very little evidence on the inter-generational transmission of war in that context. This paper tries to bridge this gap by analyzing how the insurgent violence following the invasion of Iraq in 2003

\footnotetext{
${ }^{3}$ See Koppensteiner \& Manacorda (2016) for a brief overview on the literature on maternal stress, violence, and birth outcomes
} 
has affected child health outcomes through mothers' exposure to violence during pregnancy. One important caveat of this analysis is that I am not able to test the stress mechanism directly. However, I will try to argue that some of the reduced form results favor the stress mechanism over other potential mechanisms, such as access to pre-natal care or damages to the general infrastructure. I combine geo-coded data on civilian casualties with detailed information on biometric, cognitive, and behavioral outcomes for children on district level to study the intergenerationally persistent effect of war on health. I improve on the existing literature in a few ways. First, I am the first to use a novel data set with detailed information on type, severity and perpetrator of violence in Iraq and am therefore able to better differentiate between possible channels: mainly, prenatal stress versus damages to the infrastructure and access to pre-natal health care and nutrition for mothers. The vast majority of recorded incidences on violence between 2006 and 2009 are restricted to 1 civilian casualty, suggesting that most events have a very limited effect on the local infrastructure or other determinants of health. The data also distinguishes between types of violence, such as car bombings, suicide attacks, firearms or improvised explosive devices (IEDs). The analysis combines the number of casualties and the type of incidence to carefully assess the systemic versus psychological dimension of violent events. Second, I can control for potential selection into high or low violence districts. The micro-level data with multiple births in the observation period (2006-2009) allow me to compare children living in the same household. Introducing household and mother fixed effects alleviate concerns about unobservable characteristics of mothers driving the results. Additionally, this paper is the first to go beyond birth weight as a primary measure of health, following children throughout their first years of life and tracking their cognitive, motor and behavioral skills (10 child health outcomes in total). Furthermore, very detailed information on mothers and households allow for an analysis of heterogenous effects and potential mediating factors in dealing with violent events.

In line with the literature, my results suggest that there is a strong negative effect of exposure to conflict during the first trimester of pregnancy on the weight and height for age z-scores of children. These children are also less likely to recognize words and numbers, are behind on motor skills, and cannot follow simple directions or do things independently. Similar to Camacho (2008) and other studies, I do not find that any additional event beyond the first violent incident during pregnancy has an additional negative effect on child health. The results remain robust when restricting the analysis to low severity incidences (low number of casualties and low duration) with arguably little effect on local infrastructure. I also find that most of this effect comes from violence that is explicitly targeting the civilian population rather than "collateral" damage in insurgent-coalition confrontation. Overall, this paper shows that even in regions with high and continuous exposure to conflict, like in Iraq, the additional marginal effect of exposure to violence during pregnancy remains to have a significant impact on child health. I also find suggestive evidence that this effect is mainly driven by pre-natal stress rather than damages to the infrastructure which may deprive mothers of access to health care. The paper is structured as follows: in section 2 I outline the political context during the military invasion of Iraq in 2003 and describe the data sources. Section 3 will present the empirical findings, looking at the severity of violent incidences, their perpetrators, and analyzing mediating factors. Section 4 concludes. 


\section{Data and the Iraqi Context}

In the aftermath of 9/11 the United States engaged in a military operation in Afghanistan called Operation Enduring Freedom, which was subsequently extended to Iraq. The invasion of Iraq started in March 2003 and lasted for 6 weeks. While the capture of the capital was terminated within a few weeks, insurgency arose and persisted long after the military operation ended and still continues to this day. The insurgent violence emerged among Saddam loyalists first but quickly expanded to religious and militant groups. Coalition forces have struggled throughout the war to identify insurgents and gain the support of the local population (Cockburn, 2007). Continuous confrontations and acts of violence between coalition forces, insurgent, and sectarians have caused immense collateral damage in form of civilian casualties. The Iraq Body Count Project (IBC) has recorded a total of 200,000 civilian non-combatant casualties since 2003.

Iraq consists of 19 governorates (or provinces), 118 districts and has a population of about 38 Million. The country is religiously and ethnically highly segregated with Sunni Kurds in the North, Sunni Arabs in the West, Shia Arabs in the South West and a mix of Shia and Sunni in the South of the country. While the North and East of the country is densely populated, the desert area in the South-West of the country (the provinces Al-Anbar, Al-Najaf and Al-Muthanna) has the largest districts in terms of geographic area but also the most scarcely populated. There is very limited information on the socio-economic conditions immediately following the invasion of Iraq in 2003. However, there have been some efforts by local governments and international institution to collect information on the well-being of Iraqi households, such as the Iraq Living Conditions Survey in 2004 carried out by the United Nations Development Program. In the following years more effort has been directed towards a more granular analysis of the country, moving from the national to the provisional to the district level. Table 1 describes early post-invasion data on the district level that Condra \& Shapiro (2012) have collected from various sources (LandSCan, CIA, World Food Program, NGO Coordination Committee). The average household income in 2004 was about $130 \mathrm{~K}$ Iraqi Dinar, which at the time was less than 200 US Dollars. Population size varies significantly across districts and ranges from 6636 in Choman to 1.5 Million in Karkh, a district in Baghdad.

\subsection{Multiple Indicator Cluster Survey}

In collaboration with the local government, UNICEF assists countries in collecting and analyzing the situation of children and women through its international household survey initiative, called the Multiple Indicator Cluster Surveys (MICS). The MICS of 2011 is the first survey in Iraq to be representative on the district level $^{4}$. The survey collects detailed information on living conditions, mothers' birth history, and very detailed health outcomes for children under the age of 5 , sampling 35,580 households, 56,445 women (age 15-49 years) and 36,599 small children (0-4 years). About $30 \%$ of households have more than one child under the age of five. Table 2 reports the various characteristics on the household-, parent- and child-level for all households in the MICS data set that have at least one child under the age of 5 (which I call the "full sample"). Approximately 20,000 out of the total 35,000 households have at least one child under the age of 5 . About

\footnotetext{
${ }^{4}$ Previous MICSs carried out in 2000 and 2006 were only representative on the provincial level
} 
12,000 mothers gave birth to multiple children during the relevant observation period between 2006 and 2009. This is important for the estimation strategy, because I will include household fixed effects (I call the sub sample of households with multiple children "sibling sample"). Parents in the sibling sample are less educated, younger and less wealthy than in their counterparts in the full sample.

Information on infant health outcomes include classical biometric indicators (measured by the interviewer), such as the Height for Age Z-Score and the Weight for Age Z-Score. The World Health Organization uses these z-scores as a way to express the distance between an individual child's height/weight and the average height/weight of comparable children in the reference population taking into account the dispersion of the distribution $\left(Z-\right.$ Score $=\frac{x-\mu}{\sigma}$ with $x$, as the child's height or weight, $\mu$ as the average, and $\sigma$ as the standard deviation). The WHO considers negative z-scores between -2 and -3 as malnourished and stunted; anything below -3 is categorized under severe health concerns. Additionally, child development indicators are collected in form of questions on motor skills (child is able to pick up a small object with 2 fingers), cognitive skills (child identifies at least ten letters of the alphabet, reads at least four simple, popular words, knows name and recognizes symbols of all numbers from 1-10), behavior (child follows simple directions, is able to do something independently, gets along well with other children, kicks, bites or hits other children or adults, gets distracted easily, is sometimes to sick to play). These more complex health indicators were not collected in all households but for a sub-sample of about 13,000 children (out of 36,000 children). The randomization was made at the household level such that all children under the age of 5 in the randomly selected household were tested. 24,000 children under the age of 5 have a sibling that is also under the age of 5 . Health outcomes for children that have siblings of similar age are generally worse, they tend to weigh less and be smaller. With regards to cognitive, behavioral and motor skills children in both samples perform similarly well. Additional to information on children, there is a vast array of household and parents' characteristics, including detailed information on household size, composition, and wealth, as well as information on parents' education, labor market status, proxies for religiosity and a limited number of attitudinal questions ${ }^{5}$.

\subsection{Data on Civilian Casualties}

The IBC provides daily geo-coded information on the location of the attack, the perpetrators of the attack (coalition, insurgent, sectarian, unknown), the type of attack (mortars, missiles, suicide attacks, snipers, improvised explosive devices (IEDs), rocket propelled grenades (RPGs), car bombs, and small arms fire, usually with assault riffles). Their data is gathered from media reports, hospital documentation, morgues and other sources. In cooperation with the IBC Condra \& Shapiro (2012) assign 19,961 violent incidences to districts for the period between 2003 to 2009, accounting for a total of 59,245 civilian deaths. Figure 1 depicts the total number of violent incidences and civilian casualties between 2003 and 2009.

This paper follows Condra \& Shapiro (2012) to divide killings into 4 categories:

1. Insurgent killings of civilians that occur in the course of attacking Coalition or Iraqi government targets; this category explicitly excludes insurgent killings that are unrelated to attacks and are better classified

\footnotetext{
${ }^{5}$ Appendix shows table with correlation between all control variables and main health outcomes
} 
as intimidation killings related to dynamics of the civil war

2. Coalition killings of civilians

3. Sectarian killings defined as those conducted by an organization representing an ethnic group and which did not occur in the context of attacks on Coalition or Iraqi forces

4. Unknown killings, where a clear perpetrator could not be identified. This last category captures much of the violence associated with ethnic cleansing, reprisal killings, and the like, where claims of responsibility were rarely made and bodies were often simply dropped by the side of the road

In the observation period between 2003 and 2009, half of the recorded violent incidences involve only one civilian casualty. Generally, casualty numbers are in the one digits, only $5.85 \%$ involve more than 10 casualties and the sample includes 70 observations with more than 100 casualties. Events with very high civilian casualties occured almost exclusively in Baghdad. The vast majority of incidences, more than 70\%, involves sectarian forces. However, coalition attacks have been the most fatal ones, resulting, for instance, in a violent episode of 30 days (July 1st to 30th 2006) that took 1098 civilian lives in Baghdad. Figure 2 depicts the distribution of the log number of casualties between 2006 and 2009 (relevant observation period). One concern about the accuracy of the Condra \& Shapiro (2012) data concerns the violent incidences that could not be attributed to a specific district. On the one hand, reporters may avoid high-violence environments and not report stories from there. On the other hand, the opposite bias could be present if high violence areas attract the most public attention in the first place. In order to address this concern, the authors use 2,612 incidents for which the governorate is known but the district is not and analyze whether the proportion of non-attributable incidents at the governorate correlates with levels of violence. The authors do not find a significant correlation that would suggest a systemic bias of non-attributable incidences. In order to further check the accuracy of the data, I use an alternative data set, namely the unclassified data from MNFI SIGACTS III ${ }^{6}$, which are all incidents reported to Multi-National Force-Iraq (MNFI) through daily Significant Activity Reports (SIGACTS). The data set covers all known attacks on Coalition forces, Iraqi Security Forces, the civilian population, and infrastructure between 2004 and 2008. The data do not capture the perpetrator of violence and are only recorded if they involve coalition forces in some way. In contrast to the IBC data, they also include incidences with no casualties. Comparing the yearly activities on the district level between the two data sets, there is a very high correlation of about 0.8 which is significant at the $1 \%$ level. Given the very limited data sources on district level violent incidences in Iraq, I consider this one of the few possible sanity check for the accuracy of the IBC data.

An important feature of the violence data is the distinction between coalition and insurgent violence as compared to sectarian violence. While all casualties reported are civilian casualties, the casualties resulting from coalition-insurgent confrontation are considered "non-targeted collateral damage", e.g. civilians dying in the crossfire. Sectarian violence are killings by a clearly identified militia targeted at the civilian population. Table 3 shows the breakdown of violent incidence by type and perpetrator. The data provided by Condra

\footnotetext{
${ }^{6}$ The data is made available to the Empirical Studies of Conflict (ESOC) Project and used in a different context in Berman et al. (2011)
} 
\& Shapiro (2012) include a descriptive section on the type of violent act perpetrated. Using key word searches in the incidence descriptions, I created 5 categories of attacks. These categories are not mutually exclusive since the same incidence can contain multiple types of violence. I distinguish between suicide bombings, other bombs and explosions (typically so-called Improvised Explosive Devices), airstrikes and missiles (which is mostly long-distance weaponry or military planes), gunfire, and execution or torture. Since violent incidences can involve multiple perpetrators and combine different types of violence, the shares reported do not add to 100 percent. Almost $60 \%$ of incidences with civilian casualties involved gun violence. Almost one quarter involved executions and torture, which were mostly perpetrated by sectarian agents, who are also the principal source behind violent incidences. However, the majority of suicide bombings between 2003 and 2009 were caused by insurgent rather sectarian agents. Table 4 reports the severity of the various incidences by perpetrator. I only use violent incidences with a unique and clearly identified perpetrator. 17,500 of the 18,500 recorded events only last one day. The average duration of a violent episode is between 1 and 1.5 days. For coalition forces they can last up to 31 days. There are only 10 incidences that lasted longer than one month and they were all perpetrated by sectarian agents. In the empirical analysis I will treat each day as a separate violent incidence. I expect this to downward bias the results as I treat every day as a new event, although we know from previous research that additional violent episodes beyond the first incidence typically show no effect (Camacho, 2008). Since the main analysis will include household fixed effects (looking at differences between siblings), I compare the sources of violence between the full sample and the sibling sample to see whether there are systematic differences in the type of exposure to violence across those sub-samples. Figure 5 shows a breakdown of exposure to violence by perpetrator and the sources of violence are almost identical across the two groups.

Table 5 links the perpetrator of violence as well as the number of incidences and the number of casualties to various district characteristics at baseline. In particular, I look at population size, the share of the rural and urban population, the ethnic composition, the presence and accessibility of natural resources, an indicator for public service instability (measuring the frequency of power and water outages) and the unemployment rate. The number of violent incidences and the number of casualties is positively and significantly correlated with the population size of a district and the instability of public services. Districts with a higher share of rural population experience fewer incidences. Incidences involving coalition forces are less frequent in districts with a high share of Sunnis. Insurgent attacks happen in more urban districts. Sectarian violence is not systematically correlated with district characteristics at baseline.

In order to link district-level data on violent incidences with child health outcomes, I use the exact birthdays of the children under the age of 5 from the MICS 2011 and calculate their period in-utero backward. I drop observations where there is no information on the birthday of the children. The earliest date of conception is five years and 9 months before the time of the first MICS 2011 interview, e.g. September 2005. There will be some measurement error, particularly for the first trimester, as I cannot account for early births (those are not recorded in the MICS). Instead, I assume that all children are carried to full term. Consequently, I may attribute a violent incidence that happened before birth falsely to the in-utero period of the child, e.g. I consider a child that was not treated as treated. In this case the bias would go 
against finding a systematic difference between health outcomes of siblings and the results I present are lower bound estimates. Once I have assigned in-utero periods to all children in the MICS data set, I construct the final data set which consists of the overlap period between all recorded incidences in the IBC data set and the earliest birth in the 2011 MICS data set (see Figure 3). This leaves me with the relevant period of observation from 2006 to 2009.

\section{Empirical Results}

\subsection{Identification Strategy}

I observe health outcomes $Y$ of child $i$ living in household $h$ located in district $d$ in 2011 and trace back their in-utero exposure to violence in each of the trimesters. The vector of control variables $X$ includes household-, parent- and child-level characteristics. I fist introduce district and then household fixed effects in the regression. Standard errors are clustered at the district level. The most demanding specification with household fixed effects writes as follows:

$$
Y_{i h d}=\beta_{0}+\beta_{1} \text { event }_{d * \text { trim }_{1}}+\beta_{2} \text { event }_{d * \text { trim }_{2}}+\beta_{3} \text { event }_{d * \text { trim }_{3}}+\beta_{4} X_{i h d}+\gamma_{h}+\varepsilon_{i h d}
$$

The vector of control variables $X_{i h d}$ is listed in Table 2 and includes the household size, the household wealth, mother and father characteristics, such as their age, education, their employment status. When we include household fixed effects, all of these variables will be accounted for but child-level controls include the gender of the child, whether he or she has a twin sibling, their age and line number (e.g. whether the child is first, second or third born etc.). In this specific setting the child's age will somewhat act as a year fixed effect since all the information on children, including their age is recorded in 2011. Weight and height outcomes are measured as z-Scores. The coefficient for event d*trim $_{t}$ can be interpreted as follows: a violent event during pregnancy will decrease the height or weight of a child by $\beta$ standard deviations. The other health outcomes, such as the ability to recognize letters or numbers (see Table 2 for the full list of non-biometric outcomes), are based on survey questions and are binary. For those outcomes I run a logistic model, where the coefficients of interest are presented as odds ratios, e.g. they indicate the likelihood of the respective characteristic occurring in a child.

It is important to note that the treatment is at the district level and therefore uniform across all mothers within a district. The violent incidences are observed at a certain date in a certain district and affect everyone. The within district variation is at the child level and comes from the different timing of pregnancy and the timing of violent incidences. This is why it is possible in this analysis to include district fixed effects although outcomes are only observed once in 2011 and mothers are uniformly treated within a district. Consequently, the structure of the data set does not allow me to look at the effects of violence on parent-level characteristics, such as labor market status, wealth or mental health - at least within districts. Comparisons of parent-level outcomes across districts are difficult to interpret as the level of violence is endogeneous to many district level characteristics that I am not able to control for due to lack of data. It is 
also worth noting that all children in the data set were exposed to a violent incidence at some point after they have been born (except for a few districts in the Kurdish region that have not experienced any incidences during the observation period). All of these events will naturally have an impact on child health a few years later. In this high violent environment, I am only testing whether an additional incidence during pregnancy further worsens health outcomes. On the one hand, it would be surprising to see that the marginal effect of a violent incidence during pregnancy still exists, even in contexts like Iraq. On the other hand, the literature discussed in the previous sections supports the notion that small events in early stages of pregnancy can have significant effects in the long-run and that exogenous shocks are easier to mitigate in later stages of pregnancy and early childhood.

The analysis of exposure to violence on an aggregate level leaves the risk for potential confounding factors to drive the results. There may be unobservable characteristics that simultaneously correlate with exposure to violence and determinants that negatively impact child health outcomes. For instance, selection into crime-ridden neighborhoods based on risk aversion, job flexibility or other unobservable characteristics. Exploiting the within-household variation in exposure to violence during pregnancy can remedy this concern. We compare siblings that were born very shortly after one another (maximum 2.5 years age difference) and look at how their health outcomes are related their in-utero exposure to violence. The MICS data set contains information on 34,660 children with exact birth dates, for which 30,483 have information on height and weight. These children are spread over 20,031 unique households. Table 6 shows the probability of treatment by household for the full an the sibling sample. In the full sample households 11,073 have experienced a violent incidence during pregnancy, either for some or all of their children (see second and third row). The overall probability of treatment therefore lies at around 55\%. In the sibling sample, e.g. the sample that only includes households that have had multiple children during the relevant observation period between 2006 and 2009, the probability of treatment lies at $66 \%$. The only variation I can exploit is households that have at least one child that was exposed to conflict during pregnancy but also at least another child that has not been exposed. Out of the 11 thousand treated households, there are about 6.5 thousand households in which mothers have been exposed to a violent incidence during all of their pregnancies (if they have one or multiple children); in about 4.5 thousand households, not all children have been treated. When including the household fixed effects, the analysis therefore exploits the variation in health outcomes for siblings within those 4,558 households (see second row of Table 6).

\subsection{Baseline Results and Robustness Checks}

Table 7 reports the coefficients for the effect of violent incidences on biometric outcomes for children, successively introducing district and household fixed effects. The upper section of the table (Panel A) shows results for any event occurring during pregnancy on the Height for Age Z-score and the Weight for Age Z-Score, the bottom part (Panel B) splits violent incidences by trimester of pregnancy. With the introduction of district fixed effects in columns (2) and (5), I control for non-time varying district-level heterogeneity. During the observation period there was no systematic collection of time-varying economic and demographic data on district level. In order to account for household-level unobserved heterogeneity, in columns (3) and (6) I add 
household fixed effects. In line with other results in the literature (Mansour \& Rees, 2012; Camacho, 2008; Koppensteiner \& Manacorda, 2016), the OLS results for the effect of a violent incidence during pregnancy has a strong negative effect on the height and weight of children. This result is robust to introducing household fixed effects, comparing children born in the same household in a 2.5 year span, one having been exposed to a violent incidence in-utero and the other not having been exposed. While the coefficient for the height for age z-score remains virtually the same from column (2) to (3), the coefficient for the weight for age z-score increases. Consequently, the fixed effects capture unobserved household characteristics that upward bias the estimation results in column (5). In terms of magnitude, a child that was exposed to a violent event during pregnancy is typically 0.13 standard deviations below the mean in terms of weight (say, 370 grams for a one year old) and height (say, $2.7 \mathrm{~cm}$ for a one-year old). Overall, it may be surprising to find such a strong effect in this setting. The level of conflict and violence is generally very high in Iraqi districts and one does not necessarily expect an additional violent incidence during pregnancy to have a strong marginal effect on health outcomes. In principle, all households are exposed to violence at some point during the observation period (only some Kurdish districts did not have an incidence between 2006 and 2009). The estimated effect solely represents the additional effect the exposure to violence has when it occurs during pregnancy.

In Panel B, I present the results for splitting the event timing into the three trimesters of the pregnancy. The medical literature proposes that the production of the stress-induced hormone $\mathrm{CRH}$ has the most prominent effect on birth outcomes during the first trimester of pregnancy, e.g. children are most sensitive to maternal stress in early stages of pregnancy (Glynn et al., 2001). This is confirmed in Panel B of Table 7. Most of the adverse effect of conflict on height and weight comes from events that occurred during the first trimester. As mentioned in the previous section, I will have some measurement error around the cut-off between the pre-conception period and the first trimester. As I cannot identify whether the child was an early birth, I assume children were carried to full term. This will create some inaccuracy at the beginning of the pregnancy, which manifests itself in the joint significance of a violent incidence over all trimesters (Panel A, column 3) but not when assigning events to certain trimesters (Panel B, column 3). This only seems to be a problem for the height for age z-score, rather than the weight for age z-score.

One important source of bias in this analysis is the potential miscarriages caused by violent incidences. László et al. (2014) show for stressful events during pregnancy (the loss of a family member), that the probability of miscarriage increases. This could also be the case for exposure to violence in Iraq. The MICS data set does not include information on miscarriages (and their timing). Consequently, women that have been exposed to violence and experienced a miscarriage as a consequence will not appear in the treatment group although they are the ones most severely affected by it. One thought experiment would be to consider all miscarriages as births with severe damage to weight and height. It follows that the observed birth outcomes of the treatment group are positively selected, as they exclude all miscarriages. This could downward bias the estimates, especially when I also include large scale events that are more likely to have a bigger impact on the probability of miscarriage (through factors additional to stress, such shocks to income, infrastructure etc.).

Another potential bias is unobserved heterogeneity on the household level, including both time- 
variant and time-invariant components. Using household fixed effects alleviates some concerns about timeinvariant unobserved heterogeneity. For instance, households with different levels of risk aversion (independent of income, education or other observables) that lead to a differential selection into violence-ridden neighborhoods but also simultaneously impact child health. However, I am not able to control for timevarying unobserved heterogeneity. Since the time-frame of two to three years is not very long, I expect variation in that period to be rather low. Nevertheless, there may be households that have, for instance, migrated between the birth of their children. Since I have no information on migration history (or any other proxy, such as district of birth of mother or father), I cannot directly control for this problem. I observe all households that live in a certain district in 2011 and I trace back the date violent incidences to the in-utero period of the respective children. I expect that if households moved in response to violence(if households move but there is no violent related selection, that would not bias the estimate) it would be moving out of rather than moving into violent districts. This selective out-migration implies that I will include households that were treated in the control group, e.g. mothers that were exposed to a violent incidence during pregnancy and now live in a more peaceful neighborhood will be considered not-treated. Consequently, the point estimate is likely a lower bound estimate for the effect of in-utero stress on child health outcomes. Although it is reasonable to believe that the direction of the bias goes int he opposite direction of the estimation, I use a different data source to verify whether internal migration was a major determinant in the demographic composition of districts. The Iraq Household Socio-Economic Survey (IHSES) is a large scale survey conducted by the Iraqi Central Office for Statistics and supported by the World Bank, that covers over 25,000 Iraqi households and over 175,000 individuals in the year 2012. The data set contains detailed information on the migration history of respondents. It asks about the year and month of migration and respondents specify the reason for which they moved. Specifically, the IHSES asks Did stay for 6 months continuously in another place?, which also captures short-term displacements. Overall, $18 \%$ of respondents have been living in a different place continuously for at least 6 months. The recorded timings of migration go back as far as 1930. Table 8 describes the share of individuals that migrated in the period of interest e.g. between 2006 and 2011, distinguishing between different reasons for migration. Out of the people that moved in the observation period (about 1,600 out of more than 175,000 individuals), around 11\% moved for reasons of conflict, security, forced displacement and other forms of violence-related reasons. This makes up even a smaller percentage of the full sample: out of all recorded responses in 2012 only $0.01 \%$ of individuals moved due to conflict between 2006 and 2011. These numbers may alleviate some concerns about the potential biases introduced through migration.

As outlined in the previous section, I include the age of the child as recorded in 2011, which is similar to a continuous time control variable. However, this assumes that the effect of time or age is linear in this context. For this reason, I include the birth year of children separately in Table 9. The sample consists of children born in 2006,2007, 2008 and in 2009; the omitted category is 2006. Children born in later years (particularly in 2008 and 2009) are more likely to be stunted and malnourished. The specifications include both household and district fixed effects. I successively introduce the full set of control variables. The birth year dummies in combination with household fixed effects capture a lot of the variance in the data, as the 
comparison now is not between siblings with the same age gap across households, but siblings of the same age across households. When I include only district fixed effects, I find consistently negative effects of an incidence during the first trimester on the height and weight for age z-scores. When including household fixed effects in columns $(3,4$ and 7,8$)$, only the weight for age indicator remains significant. However, this is consistent with the baseline results of Table 7 . The effect for the specification with birth year dummies is slightly smaller and less significant than in the baseline regression but the estimates are not significantly different from each other.

\subsubsection{Severity of Incidence, Intensity of Exposure and Violence before Pregnancy}

Table 10 presents robustness checks on the baseline results presented in Table 7. First, I re-run the regression in columns (3) and (6) of Table 7, now using only incidences with one casualty. I expect that incidences of limited severity, e.g. low casualty and low duration, do not have an additional impact on the infrastructure or access to health. Most of the one casualty incidences are caused by gunfire, rather than explosions through bombs or landmines, which are the incidences with the highest potential to destroy critical infrastructure, such as roads, sanitary systems, or access to hospitals and nutrition. As reported in columns (1) and (2), limiting the sample to low-casualty incidences does not alter the results. On the contrary, the size of the effect becomes marginally larger, suggesting that including large scale incidences upward biases the results. This is not surprising, as these big events are more likely to result in a miscarriage. As discussed above, the children observed in the data are positively selected along health outcomes, as the children who would have had the worse health outcomes did not survive. In columns (3) and (4) of Table 10, I look at potential non-linearities in the exposure to violence. I control for the absolute number of events by trimester to analyze whether the intensity of exposure has a marginal effect on child health. The results are in line with previous findings, that additional exposure to conflict and violence does not have an effect on child health (Koppensteiner \& Manacorda, 2016; Camacho, 2008). There may also be concerns that there is differential selection in the decision to become pregnant. One could argue that in times of high violence only those women decide to become pregnant that would have had worse child health outcomes in the first place, for instance less educated women or poorer women that do not have access to contraception. In order to remedy this concern, I control for the number of events three months prior to pregnancy. If the decision to become pregnant is differentially influenced by conditions before pregnancy, including the level of violence before conception can control for this possible selection. In columns (7) and (8) report the estimation results, excluding the 9 districts of Baghdad and only including low casualty incidences. The capital, Baghdad, is particularly war-torn, ethnically heterogeneous and densely populated. Although these effects should not matter when including district or household fixed effects, I want to rule out that my estimates are entirely driven by incidences in the capital. The estimates remain robust to the exclusion of districts in Baghdad. In Table 11, I do an additional check to see whether other structural effects may impact these results. In this sample I only use events that had one casualty and that came from direct gunfire. This means that the perpetrator shot one single civilian with a direct gunshot. This event is very unlikely to cause damages to the infrastructure or trigger curfews, as those are usually initiated after bombs or explosions or more 
large scale events with multiple casualties. Despite the tight restriction, I still find a negative and significant effects of this violent incidence on children's health.

\subsubsection{Alternative Outcomes: Cognitive-, Motor-, and Behavioral Skills}

The effects of in-utero exposure to violence on child health, goes beyond only physical measures. It can also extend to cognitive, motor, and behavioral skills. The rich data of the MICS allows me to extend the analysis to other health outcomes that shape long-run socio-econmic success of children. Non biometric outcomes are taken from survey questions of the Multiple Indicator Cluster Survey. Not all questions were asked in all households. The selection of whether or how many questions are asked is randomized at the household level. This is why, the umber of observations available for each question vary across questions. Table 12 shows the correlation between the biometric and alternative outcomes. Height and weight are not just proxies for cognitive skills, motor skills or behavior. Overall the correlation is very low (no higher than 0.05) and is not significant for many alternative outcomes, such as getting along with other children, being sick very often, the ability to pick up objects, or the ability follow simple directions or do things independently.

Table 13 reports the odds-ratios of a conditional (fixed-effects) logistic regression. The number of observations at the bottom of the two Panels of Table 13, report the number of households that have had multiple children during the observation period and have information on non-biometric outcomes. Note that all results are reported for one casualty incidences, events with higher severity are excluded from the analysis. The first three columns of Panel A, test whether 1) the child is able to identify at least 10 letters of the alphabet 2) if the child can read at least four simple, popular words, and 3) if the child knows the name and recognizes the symbol of all numbers from 1 to 10. The results are striking: among children in the same household, those who have been exposed to violence in-utero during the first and second trimester are almost 70 to $80 \%$ less likely to recognize letters or whole words. In column 4) I report the results for motor skills of children, in particular whether they are able to pick up an object with two fingers. Children whose mothers were exposed to a violent incidence during pregnancy are only half as likely to pick up an object with two fingers. I do not find any evidence of a higher likelihood to be sick (see Panel A, column 6). Considering the low and weak correlation between biometric and alternative outcomes (in particular, objects, indep, children, and distract), I can be assured that what I pick up in behavioral or cognitive skills are not just proxies for worse physical conditions of children.

In Panel B of Table 13, I report behavioral outcomes for children as reported by parents. I cannot rule out that mothers who have been exposed to violence more, will adjust behaviorally and therefore not only answer these questions differently from women who have not been exposed, but they could contribute to the adverse behavior of their children. However, I expect that this behavioral adjustment should not be different across children (especially not those with a very small age gap, like in this context). The fixed-effects should therefore control for behavioral adjustments on the level of the mother. The behavioral outcomes address the questions of whether 1)the child is able to follow simple directions 2) the child can do things independently 3) the child gets along with other children 4) the child kicks or bites adults or other children or 5) whether or not it is easily distracted. Similar to the findings on cognitive and motor skills, incidences 
of violence in-utero substantially decrease the likelihood that children are able to something independently or get along with other children (more than half as likely, irrespective of the timing of the violent incidence) and less likely to get along well with other children. Exposed children are also more easily distracted. I do not find an effect of the child's likelihood to follow directions or being violent towards other children or adults. Considering that I am comparing children that live in the same household and enjoy the same education and care taking, the magnitude of these results is striking.

Nevertheless, testing multiple hypothesis simultaneously - as I do in this case with the effect of a violent incidence during pregnancy on 10 different outcomes - increases the probability of finding false positives. In order to account for this issue in Table 13 I use Bonferroni adjusted p-values, which divides the critical value $\alpha$ by the number of tested outcomes $n$ to receive the adjusted critical value $\frac{\alpha}{n}$. The Bonferroni method is quite conservative as it assumes that all outcomes are independently distributed, which not entirely the case for the child health outcomes. As shown in Table 12, some of non-biometric outcomes are highly correlated with one another and there means are not significantly different from each other. Therefore, the Bonferroni adjustment is a strict measure of significance in this case. I indicate outcomes that are significant at the $10 \%$ under this method with an $a$. Children that were exposed to violence in-utero are less likely to recognize letters, less likely to do things independently and are less likely to get along with other children.

Overall the baseline results show strong evidence for a detrimental effect of in-utero exposure to violence (particularly in the first trimester) on various health outcomes, including biometric but also cognitive and behavioral measures. Household fixed effects pick up the non-time varying component of unobserved heterogeneity on the household level, and therefore remedy concerns about selection into violent neighborhoods or behavioral differences across households. Including the frequency of events and controlling for incidences before pregnancy does not alter the results. Incidences with very few casualties (in this case only one casualty) still have an effect on child health, which is suggestive evidence for the stress mechanism rather than access to health, nutrition or damaged infrastructure.

\subsection{Heterogeneous Effects of Violence}

In order to get a better understanding of the mechanisms at hand, I will now turn to the heterogeneity of these violent incidences, not only distinguishing between perpetrator and type of violence but also looking at potential mediating factors at the household level. In the previous section, I restricted the sample to low casualty incidences to establish first evidence for the stress-mechanism. I included either incidences with only one casualty or with casualties up to four individuals. This ensures that the incidence is small enough to not affect crucial infrastructure but big enough to be picked up by the media and/or be known to the public, at least locally. The data set of Condra \& Shapiro (2012) allows me to distinguish between different perpetrators and the type of violence that has been perpetrated. I will use this information to further test the stress mechanism by looking at events that are seemingly similar in their severity (e.g. duration and number of casualties) but that are expected to differentially impact mothers' stress levels. 


\subsubsection{Perpetrator and Type of Violence}

As already outlined in section 2, the information on the perpetrator of violence was collected from media reports, hospital logs, and morgues by the Iraq Body Count Project and was categorized and assigned to Iraqi districts by Condra \& Shapiro (2012). In my analysis, I only use incidences where one unique perpetrator can be identified. It is important to understand the difference between the categorization of perpetrator as they have an implication for the main target of the violent attack. The incident is recorded as "sectarian" if it involves casualties caused by identified sectarian militia and did not happen during combat with coalition forces, e.g. these casualties occurred outside of coalition-insurgent confrontations and directly targeted the civilian population. This category combines violence by sectarian militias targeted at co-ethnics as well as violence against people from other groups. Insurgent killings of civilians that occur in the course of attacking Coalition or Iraqi government targets are recorded as "insurgent"; Coalition killings of civilians were coded as "coalition".

Table 14 shows the results for low casualty incidences ( 1 to 4 casualties) with district fixed effects. Including household fixed effects would absorb all of the variation in the data since there are rarely mothers who have been exposed to different perpetrators over different pregnancies. The results show that most of the effect of in-utero exposure to violence on child health stems from sectarian violence. The effect is slightly smaller than in the baseline regression (see Table 7, columns 2 and 5). Coalition or insurgent caused events do not seem to impact the height for age or weight for age z-scores. There may be concerns that sectarian violence is just a proxy for violence of extreme intensity, e.g. long duration and many casualties. While this concern would already be remedied by the restriction to low casualty incidences in column 1 and 2 , the correlation coefficients in Table 15 reaffirm that this concern is not valid. In fact, there is no significant correlation between the duration of an incidence and the perpetrator, and the number of casualties is even negatively correlated with sectarian caused incidences. I take this as further evidence that sectarian violence is not only capturing severity of violence. One additional concern may be that since the data set records more sectarian than insurgent or coalition incidences, the significance simply comes from statistical power. In order to alleviate this concern I take the sub-sample of incidences that are of similar magnitude among the sectarian and insurgent/coalition agents. For bombs and explosions there about 2,300 recorded incidences for sectarian agents and 1,900 for insurgent agents (only 58 for coalition forces). Running the regression on the bombs and explosions sub-sample in columns 3 and 4 confirms the previous results. Only incidences targeting the civilian population (e.g. sectarian violence) remain significant and of similar magnitude.

The particularity of sectarian violence (namely that it is specifically targeting the civilian population, rather civilians caught in coalition-insurgent confrontation) seems to be a large potential source for stress in the population. Knowing that there has been an attack against the civilian population in the same district may impact pregnant women more, than learning about a civilian casualty that was caused by crossfire. This does not mean that coalition and insurgent incidences do not contribute to the overall violent environment and worsening of living conditions but the stress-channel seem to operate more through the sectarian incidences.

Columns 5 to 8 of Table 14 show a further sub-sample analysis now distinguishing between reli- 
giously polarized and non-polarized districts. Using CIA data for Shia and Sunni population before the US invasion in 2003, I construct a herfindahl index of religious polarization on the district level. Districts in Iraq are very homogeneous. Out of the 118 districts only 14 are actually polarized, namely the minority group holding at least $20 \%$ of the population. 81 districts are completely homogeneous with only Sunnis or Shias present. This makes a sub-sample analysis for homogeneous versus polarized districts challenging. Restricting the sample to homogeneous districts increases the size of the coefficient, I find an even larger coefficient for polarized districts but the estimate is imprecise due to a much more limited number of observations. Nevertheless, the stronger effect of attacks from an opposing religious group in a homogeneous district could support the idea that stress levels may be higher in that circumstance.

\subsubsection{Education, Wealth, and Labor Market Status}

This section looks at the mitigating factors on the household level, namely age, wealth, education, and labor market status of the parents. On the one hand these will shed light on what parent characteristics will most contribute to dealing with the consequences of in-utero exposure to violence, on the other hand, it will give further insight on the potential mechanisms at hand. If violent incidences work through damages to the health system and infrastructure, we would expect that parents who enjoyed a high education and are more wealthy can absorb the negative consequences of a violent incidence more easily. If the decline in child health is psychological and stress induced, we may find little evidence for mitigating factors. Figure 4 illustrates the regression coefficients for the interaction terms in the specification with district fixed effects. While household wealth slightly remedies the negative consequences of a violent incidence during pregnancy, other determinants such as education, age or the number of other young children in the household do not have an effect. What is more striking is that controlling for education and wealth of the household, the fact that mothers work, worsens the effect of an event on children's height and weight for age scores. One potential reason for this could be that women that work will be frequenting public spaces more regularly, which could in turn affect their perceived probability of being exposed to future incidences of violence and therefore lead to particularly high stress levels.

\subsubsection{District characteristics at baseline}

While household characteristics observed in 2011 are potentially exogenous to the exposure of violence, district level characteristics at baseline, e.g. before the start of the observation period, are pre-determined and can reveal interesting heterogeneous effects. I have looked at this indirectly in Table 14 for the effect of violence in ethnically homogeneous versus heterogeneous districts. As described in the section 2, there is only very limited data available on the district level. In this section I use three different district level characteristics: i) unemployment rate in 2007 ii) share of rural population in 2008 and iii) the instability of public services (electricity and water) in 2008. I interact these baseline characteristics with the treatment variable (violent event during pregnancy). For instance, women in districts with a high share of people living in rural areas may feel less affected by violent incidences that happen in the city. Similarly, districts with weak state capacity (here: economically weak districts, districts with a high unemployment rate or districts 
that have weak public goods provision) may leave the population feel more vulnerable and less protected by security forces in the face of violent incidences. I report the results in Table 16 . I do not find any evidence that districts with low state capacity, sparsely populated or economically weak districts experience a differentially higher effect of events on women and their children. This may not be surprising if we believe that the effect of violent events during pregnancy on child outcomes in this context is primarily driven by stress rather than by damages to the infrastructure and the districts ability to absorb those.

\section{Conclusion}

The consequences of war in the Middle-East are important but have not received much attention in the economic literature. This paper combines micro-level data on child health from the Multiple Indicator Cluster Survey in Iraq with geo-coded incidences of insurgent violence from the Iraq Body Count Project to estimate the impact of in-utero exposure to violence between 2006 and 2009 on biometric, behavioral and cognitive outcomes. The results show that one single violent incidence during pregnancy significantly increases the risk of stuntedness and malnutrition, and also substantially weakens the cognitive skills and worsens behavioral outcomes. It may come as a surprise that an additional act of violence during pregnancy can still have such a strong effect on child health in an environment where conflict is part of every day life and exposure to violence has remained persistently high over the last 15 years. This emphasizes even more the importance of pre-natal conditions on long-run health for children. This evidence stands in support of the significant body of literature that emerged in the last decade and that has consistently shown the significance of shocks in-utero. However, the contexts in which this phenomenon was studied has not allowed to isolate the effect of stress from the effect of other confounding factors. Thanks to detailed data on the source of violence, I am able to identify events that have a seemingly similar impact (same duration and number of fatalities) but are perceived as more stressful by the civilian population. In particular, sectarian violence is driving the adverse effect of exposure to violence on child health, as this source of violence is specifically targeted at the civilian population and therefore perceived as particularly stressful. 


\section{References}

Adhvaryu, A., Fenske, J., \& Nyshadham, A. (2014). Early life circumstance and adult mental health. University of Oxford, Department of Economics Working Papers, 698.

Aizer, A., Stroud, L., \& Buka, S. (2016). Maternal stress and child outcomes: Evidence from siblings. Journal of Human Resources, 51(3), 523-555.

Akbulut-Yuksel, M. (2014). Children of war the long-run effects of large-scale physical destruction and warfare on children. Journal of Human resources, 49(3), 634-662.

Almond, D. (2006). Is the 1918 influenza pandemic over? long-term effects of in utero influenza exposure in the post-1940 us population. Journal of Political Economy, 114(4), 672-712.

Almond, D. \& Currie, J. (2011). Killing me softly: The fetal origins hypothesis. Journal of economic perspectives, 25(3), 153-72.

Almond, D., Currie, J., \& Duque, V. (2017). Childhood circumstances and adult outcomes: Act II. Technical report, National Bureau of Economic Research.

Almond, D., Edlund, L., \& Palme, M. (2009). Chernobyl's subclinical legacy: prenatal exposure to radioactive fallout and school outcomes in sweden. The Quarterly journal of economics, 124(4), 1729-1772.

Almond, D. \& Mazumder, B. (2011). Health capital and the prenatal environment: the effect of ramadan observance during pregnancy. American Economic Journal: Applied Economics, 3(4), 56-85.

Andalón, M., Azevedo, J. P., Rodríguez-Castelán, C., Sanfelice, V., \& Valderrama-González, D. (2016). Weather shocks and health at birth in colombia. World Development, 82, 69-82.

Banerjee, A., Duflo, E., Postel-Vinay, G., \& Watts, T. (2010). Long-run health impacts of income shocks: Wine and phylloxera in nineteenth-century france. The Review of Economics and Statistics, 92(4), 714728.

Beach, B., Ferrie, J., Saavedra, M., \& Troesken, W. (2016). Typhoid fever, water quality, and human capital formation. The Journal of Economic History, 76(1), 41-75.

Berman, E., Shapiro, J. N., \& Felter, J. H. (2011). Can hearts and minds be bought? the economics of counterinsurgency in iraq. Journal of Political Economy, 119(4), 766-819.

Beydoun, H. \& Saftlas, A. F. (2008). Physical and mental health outcomes of prenatal maternal stress in human and animal studies: a review of recent evidence. Paediatric and perinatal epidemiology, 22(5), $438-466$.

Brown, R. (2015). The mexican drug war and early-life health: The impact of violent crime on birth outcomes. Department of Economics, University of Colorado Denver. 
Camacho, A. (2008). Stress and birth weight: evidence from terrorist attacks. The American Economic Review, 98(2), 511-515.

Cockburn, P. (2007). The Occupation: War and Resistance in Iraq. University of Michigan: Verso.

Condra, L. N. \& Shapiro, J. N. (2012). Who takes the blame? the strategic effects of collateral damage. American Journal of Political Science, 56(1), 167-187.

Cunha, F., Heckman, J. J., \& Schennach, S. M. (2010). Estimating the technology of cognitive and noncognitive skill formation. Econometrica, 78(3), 883-931.

Currie, J. \& Rossin-Slater, M. (2013). Weathering the storm: Hurricanes and birth outcomes. Journal of health economics, 32(3), 487-503.

Dercon, S. \& Porter, C. (2014). Live aid revisited: long-term impacts of the 1984 ethiopian famine on children. Journal of the European Economic Association, 12(4), 927-948.

Devakumar, D., Birch, M., Osrin, D., Sondorp, E., \& Wells, J. C. (2014). The intergenerational effects of war on the health of children. BMC medicine, 12(1), 57.

Duncan, B., Mansour, H., \& Rees, D. I. (2016). It's just a game: The super bowl and low birth weight. Journal of Human Resources, (pp. 0615-7213R).

Eccleston, M. (2011). In utero exposure to maternal stress: Effects of 9/11 on birth and early schooling outcomes in new york city. Job market paper: Harvard University.

Glynn, L. M., Wadhwa, P. D., Dunkel-Schetter, C., Chicz-DeMet, A., \& Sandman, C. A. (2001). When stress happens matters: Effects of earthquake timing on stress responsivity in pregnancy. American Journal of Obstetrics and Gynecology, 184(4), $637-642$.

Isen, A., Rossin-Slater, M., \& Walker, W. R. (2017). Every breath you take - every dollar you'll make: The long-term consequences of the clean air act of 1970. Journal of Political Economy, 125(3), 848-902.

Koppensteiner, M. F. \& Manacorda, M. (2016). Violence and birth outcomes: Evidence from homicides in brazil. Journal of Development Economics, 119, 16-33.

László, K., Ananth, C., Wikström, A.-K., Svensson, T., Li, J., Olsen, J., Vestergaard, M., Obel, C., \& Cnattingius, S. (2014). Loss of a close family member the year before or during pregnancy and the risk of placental abruption: a cohort study from denmark and sweden. Psychological medicine, 44(9), 1855-1866.

Lee, C. (2014). In utero exposure to the korean war and its long-term effects on socioeconomic and health outcomes. Journal of Health Economics, 33, 76 - 93.

Majid, M. F. (2015). The persistent effects of in utero nutrition shocks over the life cycle: Evidence from ramadan fasting. Journal of Development Economics, 117, 48-57. 
Mansour, H. \& Rees, D. I. (2012). Armed conflict and birth weight: Evidence from the al-aqsa intifada. Journal of Development Economics, 99(1), 190-199.

Murthy, R. S. \& Lakshminarayana, R. (2006). Mental health consequences of war: a brief review of research findings. World Psychiatry, 5(1), 25-30.

Nasir, M. et al. (2016). Violence and Child Health Outcomes: Evidence from Mexican Drug War. Technical report, Households in Conflict Network.

Ngo, N. S. \& Horton, R. M. (2016). Climate change and fetal health: The impacts of exposure to extreme temperatures in new york city. Environmental research, 144, 158-164.

Nilsson, J. P. (2017). Alcohol availability, prenatal conditions, and long-term economic outcomes. Journal of Political Economy, 125(4), 1149-1207.

Persson, P. \& Rossin-Slater, M. (2018). Family ruptures, stress, and the mental health of the next generation. American Economic Review, 108(4-5), 1214-52.

Shah, M. \& Steinberg, B. M. (2017). Drought of opportunities: Contemporaneous and long-term impacts of rainfall shocks on human capital. Journal of Political Economy, 125(2), 527-561.

Torche, F. \& Villarreal, A. (2014). Prenatal exposure to violence and birth weight in mexico: Selectivity, exposure, and behavioral responses. American sociological review, 79(5), 966-992.

Van Ewijk, R. (2011). Long-term health effects on the next generation of ramadan fasting during pregnancy. Journal of health economics, 30(6), 1246-1260. 


\section{Appendix}

\section{$5.1 \quad$ Firgures}

Figure 1: Iraq Body Count Data by District 2003-2009

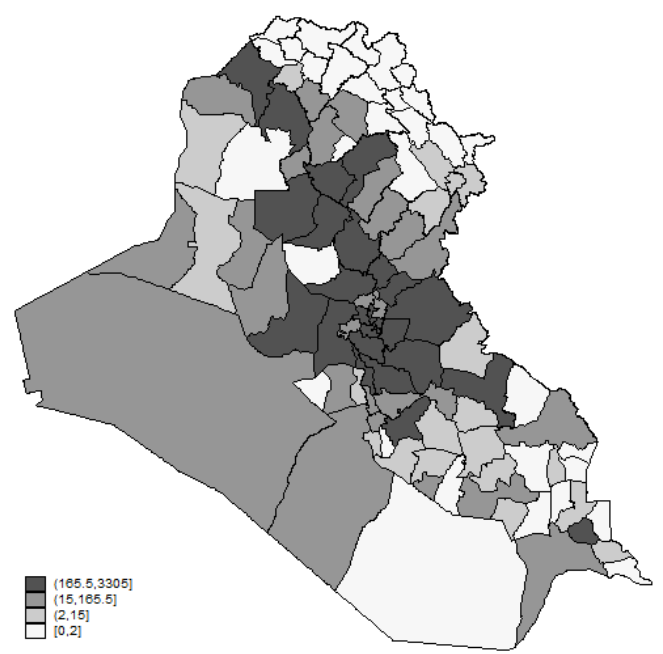

(a) Number of Violent Incidences

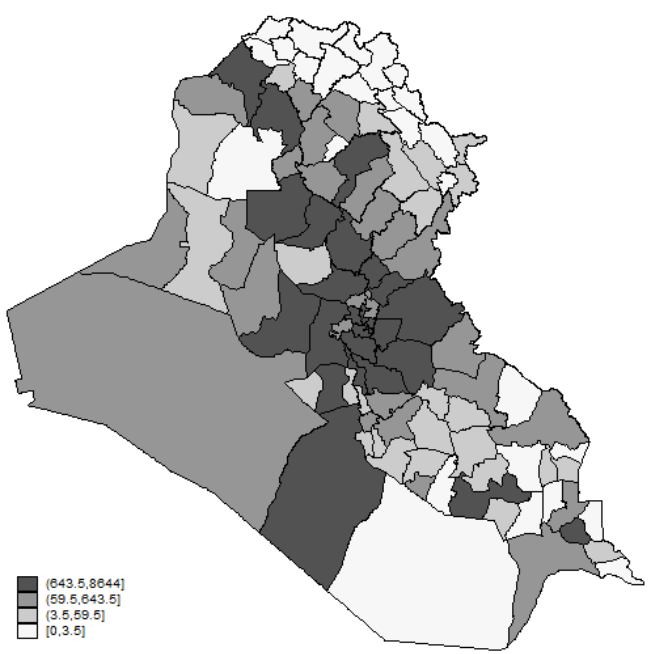

(b) Number of Civilian Casualties

Figure 2: Log Number of Casualties - low casualty cutoff

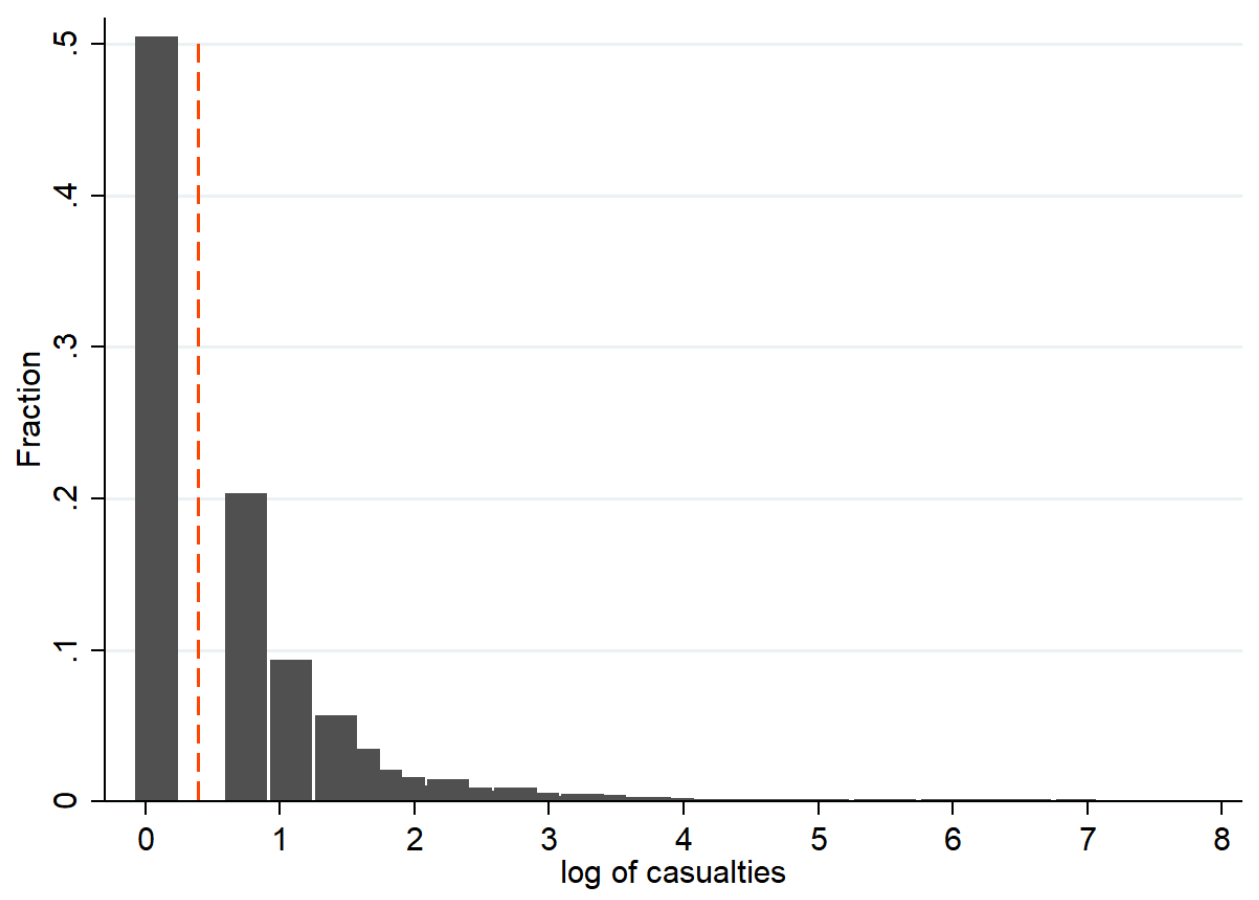


Figure 3: Construction of Data Set

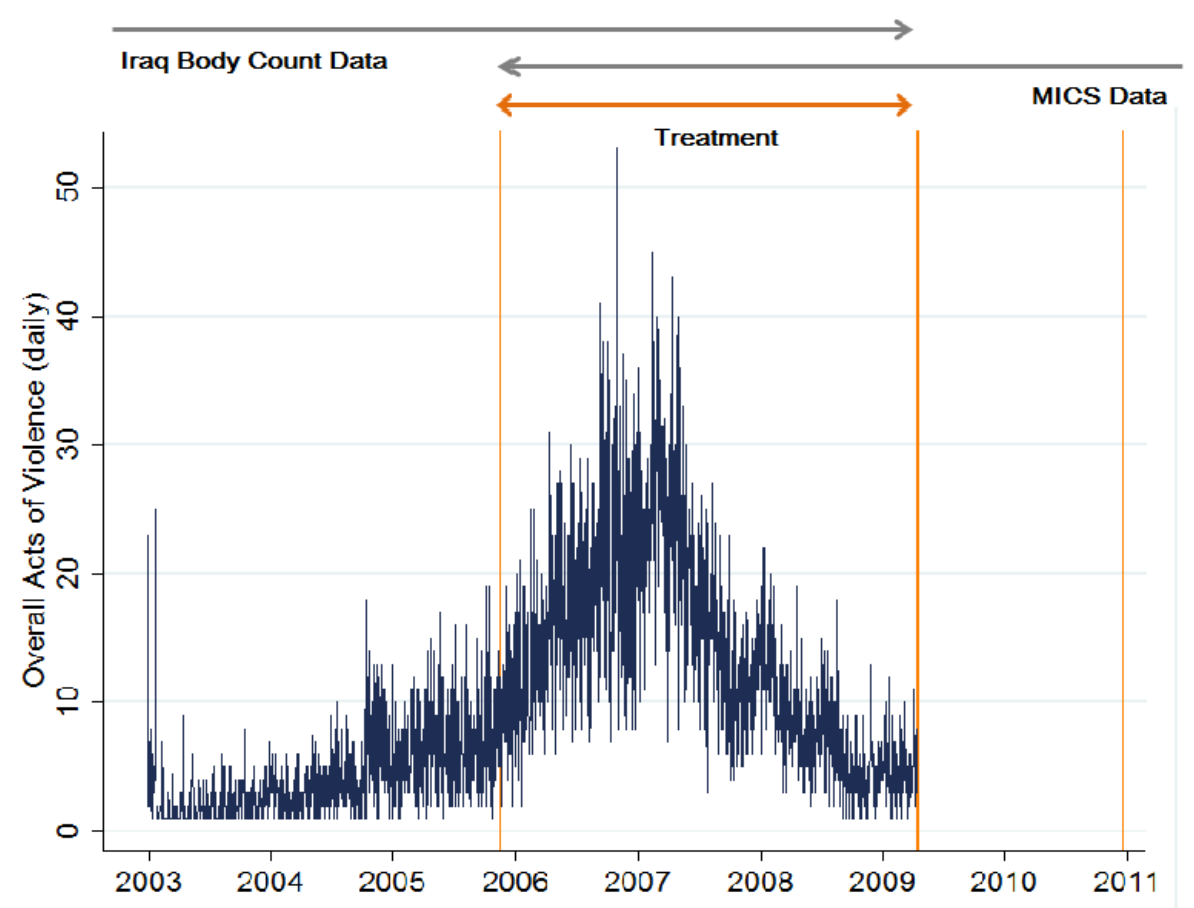

Figure 4: Interaction between Incidences of Violence during pregnancy and Household Characteristics

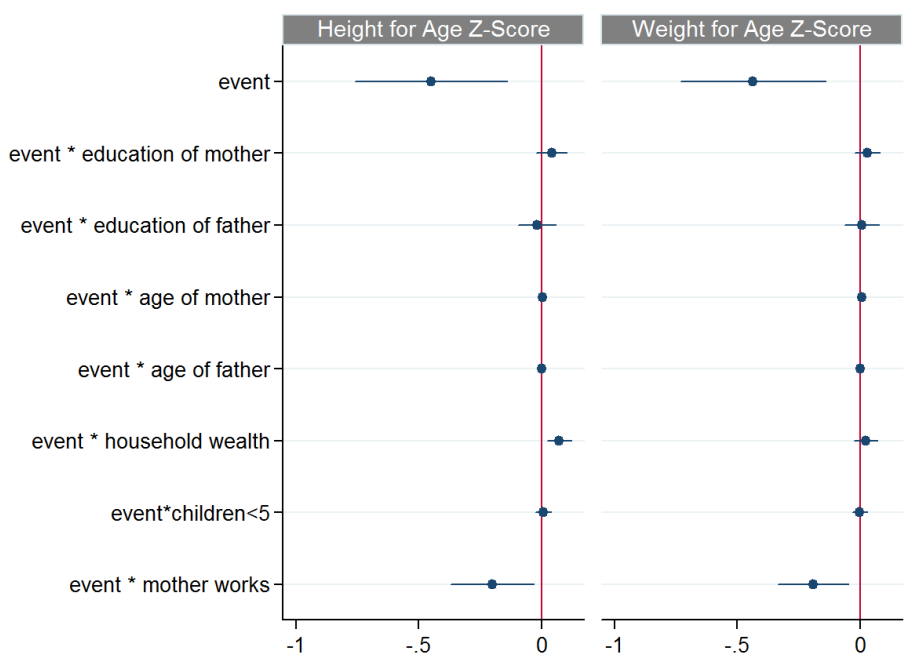


Figure 5: Exposure to Violence by Perpetrator

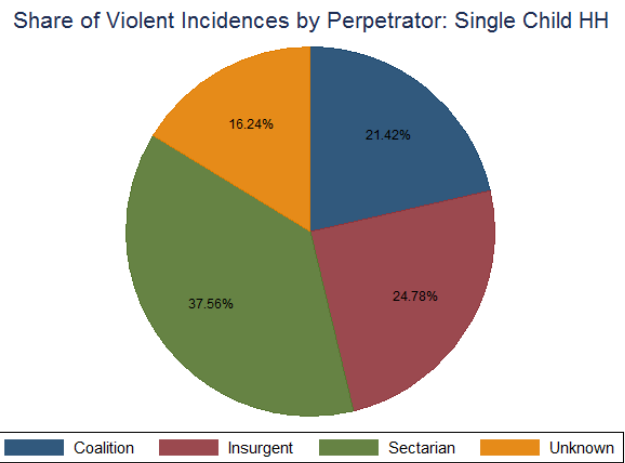

(a) HHs with only one child

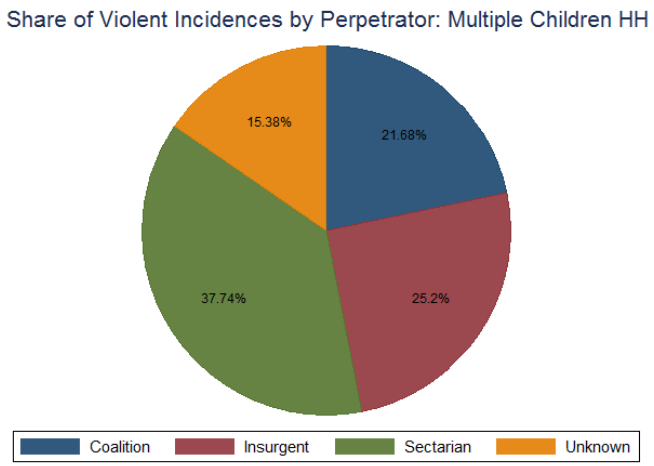

(b) HHs with multiple children

\subsection{Tables}

Table 1: Summary Statistics - District Characteristics

\begin{tabular}{l|c|c|c} 
& year recorded & mean & sd \\
\hline hh income (IQD) & 2004 & 130,804 & 23,972 \\
hh size & $2004-2007$ & 6.64 & 0.82 \\
unemployment rate & $2004-2007$ & 0.10 & 0.051 \\
sunni population & 2003 & 67,092 & 136,312 \\
kurdish population & 2003 & 47,313 & 104,950 \\
shia population & 2003 & 133,168 & 214,906 \\
total population & 2003 & 247,574 & 298,163 \\
share urban population & 2007 & 0.52 & 0.24 \\
share rural population & 2007 & 0.48 & 0.24 \\
distance to police (km) & 2004 & 2.20 & 0.52 \\
distance to public service $(\mathrm{km})$ & 2004 & 0.15 & 0.029 \\
share of hh with crime victim & 2004 & 0.009 & 0.011 \\
\hline
\end{tabular}

This Table reports available district characteristics at baseline. This data comes from various sources, including raw 2004 ILCS survey responses at the district, governorate, and sect levels. The 2004 ILCS instrument is called the "Iraq Multiple Indicator Rapid Assessment" and is available online. Raw ILCS responses are available from the Central Organization for Statistics and Information Technology of Iraq (COSIT) (see Condra \& Shapiro (2012)). Population figures and economic variables come from the World Food Program. Ethnicity data come from the CIA. Since I use both district and household fixed effects, these variables will be absorbed in our baseline results. 
Table 2: Summary statistics - Multiple Indicator Cluster Survey

\begin{tabular}{|c|c|c|c|c|c|c|c|c|}
\hline & \multicolumn{4}{|c|}{$\begin{array}{c}(1) \\
\text { Full Sample }\end{array}$} & \multicolumn{4}{|c|}{$\begin{array}{c}(2) \\
\text { Sibling Sample }\end{array}$} \\
\hline & mean & sd & $\min$ & $\max$ & mean & sd & $\min$ & $\max$ \\
\hline \multicolumn{9}{|l|}{ Household characteristics } \\
\hline Number of $\mathrm{HH}$ members & 7.57 & 3.55 & 2 & 36 & 8.36 & 4.04 & 3 & 36 \\
\hline Number of women 15 - 49 years & 1.64 & 1.06 & 0 & 11 & 1.72 & 1.16 & 0 & 11 \\
\hline Number of children under age 5 & 1.77 & 0.96 & 1 & 13 & 2.47 & 0.87 & 2 & 13 \\
\hline Total children aged 2-14 years & 3.39 & 1.87 & 1 & 20 & 3.48 & 2.09 & 1 & 20 \\
\hline Female household head & 0.05 & 0.21 & 0 & 1 & 0.05 & 0.21 & 0 & 1 \\
\hline Education of household head & 2.25 & 0.75 & 1 & 3 & 2.18 & 0.76 & 1 & 3 \\
\hline Rural & 0.43 & 0.49 & 0 & 1 & 0.47 & 0.50 & 0 & 1 \\
\hline Wealth index score & -0.07 & 1.00 & -6 & 2 & -0.17 & 1.05 & -6 & 2 \\
\hline Observations & 20,031 & & & & 10,294 & & & \\
\hline \multicolumn{9}{|l|}{ Parent characteristics } \\
\hline Mother's line number & 3.64 & 3.25 & 1 & 32 & 4.28 & 3.80 & 1 & 32 \\
\hline Father's line number & 1.89 & 2.08 & 0 & 31 & 2.25 & 2.49 & 0 & 31 \\
\hline Father's education & 2.43 & 0.78 & 1 & 9 & 2.38 & 0.77 & 1 & 9 \\
\hline Mother's education & 2.04 & 0.71 & 1 & 3 & 1.98 & 0.70 & 1 & 3 \\
\hline Age of woman & 29.96 & 6.99 & 15 & 49 & 28.73 & 6.34 & 15 & 49 \\
\hline Age of husband/partner & 34.43 & 8.27 & 15 & 92 & 33.05 & 7.59 & 16 & 85 \\
\hline Husband is relative & 0.60 & 0.49 & 0 & 1 & 0.61 & 0.49 & 0 & 1 \\
\hline Currently working & 0.09 & 0.29 & 0 & 1 & 0.09 & 0.28 & 0 & 1 \\
\hline Husband/partner has other wives & 0.06 & 0.23 & 0 & 1 & 0.06 & 0.25 & 0 & 1 \\
\hline Observations & 22,109 & & & & 12,328 & & & \\
\hline \multicolumn{9}{|l|}{ Child characteristics } \\
\hline Female & 0.49 & 0.50 & 0 & 1 & 0.49 & 0.50 & 0 & 1 \\
\hline Twin & 0.03 & 0.16 & 0 & 1 & 0.03 & 0.18 & 0 & 1 \\
\hline Line number & 7.25 & 3.76 & 2 & 36 & 7.56 & 4.08 & 2 & 36 \\
\hline Age & 3.83 & 1.58 & 1 & 6 & 3.84 & 1.58 & 1 & 6 \\
\hline \multicolumn{9}{|l|}{ Child Outcomes } \\
\hline Height for age z-score & -0.57 & 2.08 & -10 & 10 & -0.62 & 2.04 & -10 & 10 \\
\hline Weight for age z-score & -0.26 & 1.84 & -6 & 10 & -0.30 & 1.80 & -6 & 10 \\
\hline Identifies at least ten letters of the alphabet & 0.29 & 0.45 & 0 & 1 & 0.29 & 0.45 & 0 & 1 \\
\hline Reads at least four simple, popular words & 0.12 & 0.32 & 0 & 1 & 0.11 & 0.32 & 0 & 1 \\
\hline Knows name and recognizes symbol of all numbers from 1-10 & 0.21 & 0.41 & 0 & 1 & 0.20 & 0.40 & 0 & 1 \\
\hline Able to pick up small object with 2 fingers & 0.90 & 0.30 & 0 & 1 & 0.89 & 0.31 & 0 & 1 \\
\hline Sometimes too sick to play & 0.54 & 0.50 & 0 & 1 & 0.54 & 0.50 & 0 & 1 \\
\hline Follows simple directions & 0.82 & 0.39 & 0 & 1 & 0.81 & 0.39 & 0 & 1 \\
\hline Able to do something independently & 0.74 & 0.44 & 0 & 1 & 0.73 & 0.44 & 0 & 1 \\
\hline Gets along well with other children & 0.84 & 0.37 & 0 & 1 & 0.83 & 0.38 & 0 & 1 \\
\hline Kicks, bites or hits other children or adults & 0.26 & 0.44 & 0 & 1 & 0.27 & 0.45 & 0 & 1 \\
\hline Gets distracted easily & 0.44 & 0.50 & 0 & 1 & 0.45 & 0.50 & 0 & 1 \\
\hline Observations & 34,660 & & & & 24,843 & & & \\
\hline
\end{tabular}

This Table reports summary statistics from the 2011 Iraq Multiple Indicator Cluster Survey on 3 levels: the household level, the parent level and the child level. I report the summary statistics for the full sample as well as for the subset of households that has multiple children under the age of 5, which will be the sample we draw from in our household f.e. regression. The table also shows the main outcomes of interest, including biometric (height for age and weight for age z-scores) as well as cognitive, motor and behavioral skills, based on survey questions to the mother. 
Table 3: Violent Incidence Characteristics by Perpetrator

\begin{tabular}{|c|c|c|c|c|c|}
\hline & suicide bombings & bombs \& explosions & airstrikes \& missiles & gunfire & execution \& torture \\
\hline \multicolumn{6}{|l|}{ Coalition Forces } \\
\hline share & 0 & .0492 & .2409 & .6285 & .0076 \\
\hline sd & 0 & .2164 & .4278 & .4834 & .0871 \\
\hline $\mathrm{N}$ & 0 & 58 & 284 & 741 & 9 \\
\hline \multicolumn{6}{|l|}{ Insurgent Agents } \\
\hline share & .1822 & .6695 & .0718 & .2647 & .0096 \\
\hline sd & .3861 & .4705 & .2583 & .4412 & .0973 \\
\hline $\mathrm{N}$ & 515 & 1892 & 203 & 748 & 27 \\
\hline \multicolumn{6}{|l|}{ Sectarian Agents } \\
\hline share & .0268 & .1797 & .0679 & .6998 & .3158 \\
\hline sd & .1615 & .3840 & .2516 & .4584 & .4649 \\
\hline $\mathrm{N}$ & 345 & 2314 & 874 & 9009 & 4066 \\
\hline \multicolumn{6}{|l|}{$\overline{\overline{\text { Total }}}$} \\
\hline share & .0482 & .2387 & .0762 & .5878 & .2297 \\
\hline sd & .2141 & .4263 & .2653 & .4922 & .4206 \\
\hline $\mathrm{N}$ & 860 & 4264 & 1361 & 10498 & 4102 \\
\hline
\end{tabular}

Own classification of type of violence according to descriptions in "Cause of Death" column of the ESOC data (Iraq Body Count Project and Condra \& Shapiro (2012) data set), based on keyword search. Multiple classifications for a single violent incidence are possible (e.g. suicide bombings + explosions). Summary stats are provided for incidences with one unique and identified perpetrator; events with unknown perpetrator $(\mathrm{N}=981)$ or multiple perpetrators $(\mathrm{N}=602)$ are not reported.

Table 4: Severity of Violence by Perpetrator

\begin{tabular}{llll}
\hline mean & $\min$ & $\max$ & $\mathrm{N}$ \\
\hline
\end{tabular}

\begin{tabular}{lcccc}
$\begin{array}{l}\text { Coalition Forces } \\
\text { Duration (days) }\end{array}$ & 1.48 & 1 & 31 & 1179 \\
Casualties & 6.48 & 1 & 670 & 1179 \\
\hline & & & & \\
Insurgent Agents & & & & \\
Duration (days) & 1.04 & 1 & 16 & 2826 \\
Casualties & 3.58 & 1 & 80 & 2826 \\
\hline & & & & \\
Sectarian Agents & & & & \\
Duration (days) & 1.29 & 1 & 1077 & 12874 \\
Casualties & 3.11 & 1 & 1005 & 12874 \\
\hline \hline
\end{tabular}

\begin{tabular}{lllll} 
Total & & & & \\
Duration (days) & 1.26 & 1 & 1077 & 16879 \\
Casualties & 3.42 & 1 & 1005 & 16879 \\
\hline
\end{tabular}

Based on ESOC data (Iraq Body Count Project and Condra \& Shapiro (2012) data set). Summary stats are provided for incidences with one unique and identified perpetrator; events with unknown perpetrator $(\mathrm{N}=981)$ or multiple perpetrators $(\mathrm{N}=602)$ are not reported. 
Table 5: Correlation - violence (all recorded incidences 2003 to 2009) and district characteristics at baseline

\begin{tabular}{|c|c|c|c|c|c|c|}
\hline & coalition & insurgent & sectarian & unknown & incidences & casualties \\
\hline \multirow[t]{2}{*}{ population size (2003) } & -0.0896 & -0.0965 & 0.1561 & -0.0813 & 0.6951 & 0.7426 \\
\hline & 0.3957 & 0.3603 & 0.1374 & 0.4412 & 0.0000 & 0.0000 \\
\hline \multirow[t]{2}{*}{ share urban (2003) } & -0.0180 & 0.1827 & -0.0750 & -0.2097 & 0.0563 & 0.0936 \\
\hline & 0.8699 & 0.0942 & 0.4949 & 0.0540 & 0.6091 & 0.3942 \\
\hline \multirow[t]{2}{*}{ share rural (2003) } & 0.1627 & 0.0016 & -0.1708 & -0.0594 & -0.1938 & -0.2070 \\
\hline & 0.1368 & 0.9885 & 0.1181 & 0.5889 & 0.0755 & 0.0573 \\
\hline \multirow[t]{2}{*}{ Sunni population (2003) } & -0.1933 & 0.0971 & 0.0428 & -0.0481 & 0.8042 & 0.8060 \\
\hline & 0.0649 & 0.3574 & 0.6856 & 0.6488 & 0.0000 & 0.0000 \\
\hline \multirow[t]{2}{*}{ Kurdish population (2003) } & -0.1298 & 0.0397 & 0.0519 & -0.0967 & 0.0597 & -0.0013 \\
\hline & 0.2174 & 0.7071 & 0.6235 & 0.3592 & 0.5721 & 0.9902 \\
\hline \multirow[t]{2}{*}{ Shia population (2004) } & 0.0026 & -0.1293 & 0.1467 & -0.0347 & 0.4104 & 0.4825 \\
\hline & 0.9801 & 0.2194 & 0.1630 & 0.7429 & 0.0000 & 0.0000 \\
\hline \multirow[t]{2}{*}{ oil and gas fields (2002) } & -0.0502 & -0.0037 & 0.0290 & 0.0974 & 0.1016 & 0.0548 \\
\hline & 0.6345 & 0.9718 & 0.7835 & 0.3558 & 0.3354 & 0.6037 \\
\hline \multirow[t]{2}{*}{ accessible oil and gas fields (2002) } & -0.0716 & -0.0281 & 0.0692 & 0.0642 & 0.0920 & 0.0709 \\
\hline & 0.4979 & 0.7901 & 0.5119 & 0.5431 & 0.3829 & 0.5017 \\
\hline \multirow[t]{2}{*}{ public service instability (2004) } & 0.0566 & 0.1134 & -0.0234 & -0.2755 & 0.1956 & 0.2187 \\
\hline & 0.5964 & 0.2872 & 0.8264 & 0.0086 & 0.0647 & 0.0383 \\
\hline \multirow[t]{2}{*}{ unemployment rate (2004) } & 0.0798 & -0.0885 & -0.0330 & 0.3917 & -0.0980 & -0.0747 \\
\hline & 0.4494 & 0.4016 & 0.7552 & 0.0001 & 0.3525 & 0.4789 \\
\hline
\end{tabular}

Table 5 reports the correlation between characteristics of the violent incident (perpetrator, frequency, number of casualties) and characteristics of the district at baseline (e.g. before 2006), t-stats are reported beneath the correlation coefficients. This data comes from various sources, including raw 2004 ILCS survey responses at the district, governorate, and sect levels. The 2004 ILCS instrument is called the "Iraq Multiple Indicator Rapid Assessment" and is available online. Raw ILCS responses are available from the Central Organization for Statistics and Information Technology of Iraq (COSIT) (see Condra \& Shapiro (2012)). Population figures and economic variables come from the World Food Program. Ethnicity data come from the CIA. Since I use both district and household fixed effects, these variables will be absorbed in our baseline results. 
Table 6: Probability of exposure to violence during pregnancy - by household

\begin{tabular}{lcc|cc} 
& \multicolumn{2}{c}{ Full Sample } & \multicolumn{2}{c}{ Sibling Sample } \\
& $\mathrm{N}$ & share & $\mathrm{N}$ & share \\
\hline None treated & 8,958 & 0.447 & 3,394 & 0.334 \\
& & & & \\
Some treated & 4,558 & 0.228 & 4,558 & 0.217 \\
All treated & 6,515 & 0.325 & 2,202 & 0.449 \\
\hline Total & 20,031 & 1 & 10,145 & 1 \\
\hline \hline
\end{tabular}

Number of households that have a child/multiple children under the age of 5 , of which none were exposed to violence during pregnancy (first row), of which some were exposed to violence (second row), of which all were exposed to violence (third row). First column shows all households, second column shows households that have had multiple children during the relevant observation period between 2006 and 2009 . 
Table 7: OLS Result: Effect of any Event during Pregnancy or any Event in Trimester on Height and Weight for Age Z-Score

Height for Age Z-Score

Weight for Age Z-Score

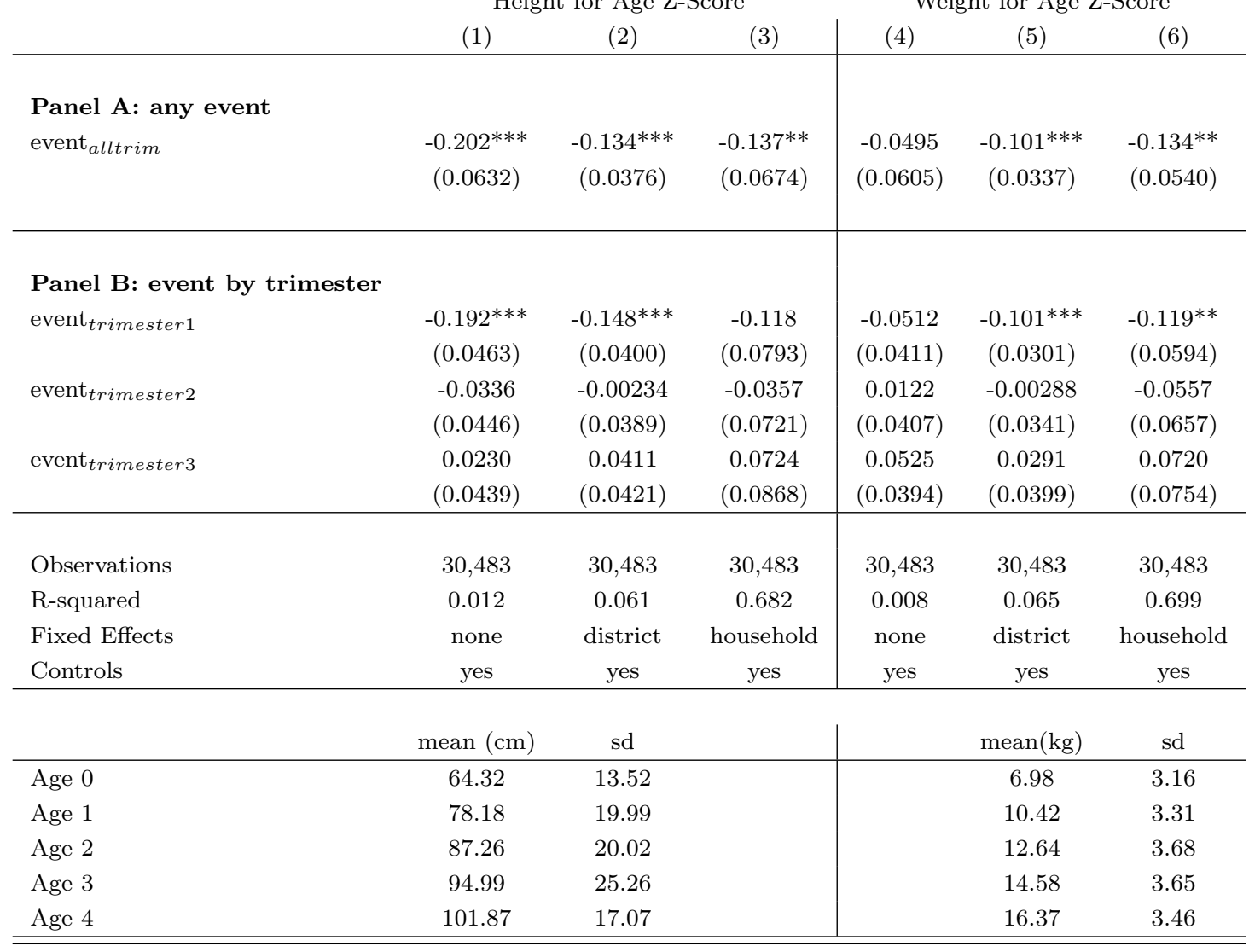

Robust standard errors in parentheses (clustered on district level), *** $\mathrm{p}<0.01, * * \mathrm{p}<0.05, * \mathrm{p}<0.1$ Constant not reported. Control Variables include: hh size, number of women 15-49 in hh, number of children under age 5, number of children between age 5 and 14, sex of hh head, education of hh head, dummy for rural hh, hh owns dwelling, hh owns agricultural land, size of land held by hh, mother's and father's line number, mother's and father's education, biological mother/father alive, mother/father age, spouse is a relative, mother/father works, father has multiple wives, sex of child, dummy for twin, line number of child

Table 8: Iraq Household Socio-Economic Survey: Reasons for Migration

\begin{tabular}{lccc} 
Reason & N & share of subsample (\%) & Share of full sample (\%) \\
\hline work & 230 & 14.51 & 0.131 \\
study or complete study & 42 & 2.65 & 0.024 \\
marriage, divorce or becoming widow & 278 & 17.54 & 0.158 \\
accompany household & 733 & 46.25 & 0.419 \\
forced displacement or migration & 51 & 3.22 & 0.029 \\
back from forced displacement or migration & 83 & 5.24 & 0.047 \\
displacement for security reason & 6 & 0.38 & 0.003 \\
conventional armed conflict & 23 & 1.45 & 0.013 \\
civil conflict & 14 & 0.88 & 0.008 \\
other & 124 & 7.82 & 0.071 \\
\hline Observations & 1,584 & \\
\hline
\end{tabular}

Table 8 uses a different data source, namely the Iraq household socio-economic survey of 2012 that asks the question "Did you stay for 6 months continuously in another place?" If yes, "What is the main reason for changing the place of residence?". The answers to the latter question are presented in this table. The full sample consists of more than 175,000 respondents, the relevant sample of migrants within the 2006 to 2009 observation period is 1,584 . 
Table 9: Robustness checks: birth-year dummies, with and without controls

\begin{tabular}{|c|c|c|c|c|c|c|c|c|}
\hline & \multicolumn{4}{|c|}{ Height for Age } & \multicolumn{4}{|c|}{ Wheight for Age } \\
\hline & $(1)$ & $(2)$ & (3) & $(4)$ & $(5)$ & $(6)$ & $(7)$ & $(8)$ \\
\hline event $_{\text {trimester } 1}$ & $\begin{array}{c}-0.144^{* * *} \\
(0.0417)\end{array}$ & $\begin{array}{c}-0.146^{* * *} \\
(0.0435)\end{array}$ & $\begin{array}{c}-0.109 \\
(0.0854)\end{array}$ & $\begin{array}{c}-0.111 \\
(0.0898)\end{array}$ & $\begin{array}{c}-0.136^{* * *} \\
(0.0340)\end{array}$ & $\begin{array}{c}-0.132^{* * *} \\
(0.0355)\end{array}$ & $\begin{array}{c}-0.107^{*} \\
(0.0566)\end{array}$ & $\begin{array}{l}-0.106^{*} \\
(0.0598)\end{array}$ \\
\hline event $_{\text {trimester } 2}$ & $\begin{array}{c}0.00938 \\
(0.0370)\end{array}$ & $\begin{array}{c}0.0401 \\
(0.0379)\end{array}$ & $\begin{array}{c}0.0171 \\
(0.0815)\end{array}$ & $\begin{array}{c}0.0283 \\
(0.0807)\end{array}$ & $\begin{array}{c}0.0287 \\
(0.0331)\end{array}$ & $\begin{array}{c}0.0650^{*} \\
(0.0339)\end{array}$ & $\begin{array}{c}0.0338 \\
(0.0647)\end{array}$ & $\begin{array}{c}0.0389 \\
(0.0735)\end{array}$ \\
\hline event $_{\text {trimester } 1}$ & $\begin{array}{c}0.0589 \\
(0.0494)\end{array}$ & $\begin{array}{c}0.0723 \\
(0.0520)\end{array}$ & $\begin{array}{c}0.0966 \\
(0.0922)\end{array}$ & $\begin{array}{c}0.119 \\
(0.0934)\end{array}$ & $\begin{array}{c}0.0532 \\
(0.0423)\end{array}$ & $\begin{array}{c}0.0673 \\
(0.0437)\end{array}$ & $\begin{array}{c}0.0746 \\
(0.0779)\end{array}$ & $\begin{array}{c}0.0810 \\
(0.0810)\end{array}$ \\
\hline birth year dumn & & & & & & & & \\
\hline 2007 & $\begin{array}{c}-0.139 * * * \\
(0.0420)\end{array}$ & $\begin{array}{c}-0.112^{* * *} \\
(0.0414)\end{array}$ & $\begin{array}{c}-0.196^{* *} \\
(0.0825)\end{array}$ & $\begin{array}{c}-0.127 \\
(0.0784)\end{array}$ & $\begin{array}{c}-0.0788^{*} \\
(0.0400)\end{array}$ & $\begin{array}{l}-0.0578 \\
(0.0394)\end{array}$ & $\begin{array}{c}-0.109 \\
(0.0755)\end{array}$ & $\begin{array}{c}-0.0578 \\
(0.0708)\end{array}$ \\
\hline 2008 & $\begin{array}{c}-0.0953^{* *} \\
(0.0461)\end{array}$ & $\begin{array}{c}-0.0849^{*} \\
(0.0460)\end{array}$ & $\begin{array}{c}-0.134 \\
(0.0827)\end{array}$ & $\begin{array}{c}-0.113 \\
(0.0814)\end{array}$ & $\begin{array}{c}-0.140^{* * *} \\
(0.0371)\end{array}$ & $\begin{array}{c}-0.137^{* * *} \\
(0.0347)\end{array}$ & $\begin{array}{c}-0.170^{* *} \\
(0.0710)\end{array}$ & $\begin{array}{c}-0.161^{* *} \\
(0.0697)\end{array}$ \\
\hline 2009 & $\begin{array}{c}-0.227^{* * *} \\
(0.0380)\end{array}$ & $\begin{array}{c}-0.230 * * * \\
(0.0386)\end{array}$ & $\begin{array}{c}-0.297^{* * *} \\
(0.0715)\end{array}$ & $\begin{array}{c}-0.296^{* * *} \\
(0.0694)\end{array}$ & $\begin{array}{c}-0.134^{* * *} \\
(0.0330)\end{array}$ & $\begin{array}{c}-0.142^{* * *} \\
(0.0343)\end{array}$ & $\begin{array}{c}-0.205^{* * *} \\
(0.0608)\end{array}$ & $\begin{array}{r}-0.201^{* * *} \\
(0.0634)\end{array}$ \\
\hline Observations & 34,660 & 30,483 & 34,660 & 30,483 & 34,660 & 30,483 & 34,660 & 30,483 \\
\hline R-squared & 0.056 & 0.063 & 0.695 & 0.684 & 0.065 & 0.069 & 0.710 & 0.700 \\
\hline Fixed Effects & district & district & household & household & district & district & household & household \\
\hline Controls & no & yes & no & yes & no & yes & no & yes \\
\hline
\end{tabular}

Robust standard errors in parentheses (clustered on district level), *** p $<0.01, * * \mathrm{p}<0.05, *$ p $<0.1$ Constant not reported. Dummies for birth years 2006, 2007, 2008, and 2009 with 2006 as omitted category. Control Variables include: hh size, number of women 15-49 in hh, number of children under age 5 , number of children between age 5 and 14, sex of hh head, education of hh head, dummy for rural hh, hh owns dwelling, hh owns agricultural land, size of land held by hh, mother's and father's line number, mother's and father's education, biological mother/father alive, mother/father age, spouse is a relative, mother/father works, father has multiple wives, sex of child, dummy for twin, line number of child 
Table 10: Robustness checks: severity, intensity, pre-pregnancy

\begin{tabular}{|c|c|c|c|c|c|c|c|c|}
\hline & \multicolumn{2}{|c|}{ Low Casualty } & \multicolumn{2}{|c|}{ Frequency } & \multicolumn{2}{|c|}{ Pre-pregnancy } & \multicolumn{2}{|c|}{ Excl. Baghdad } \\
\hline & $\begin{array}{l}\text { Height } \\
(1)\end{array}$ & $\begin{array}{l}\text { Weight } \\
(2)\end{array}$ & $\begin{array}{l}\text { Height } \\
(3)\end{array}$ & $\begin{array}{c}\text { Weight } \\
(4)\end{array}$ & $\begin{array}{c}\text { Height } \\
(5)\end{array}$ & $\begin{array}{l}\text { Weight } \\
(6)\end{array}$ & $\begin{array}{l}\text { Height } \\
(7)\end{array}$ & $\begin{array}{c}\text { Weight } \\
(8)\end{array}$ \\
\hline event $t_{\text {trimester } 1}$ & $\begin{array}{l}-0.174^{*} \\
(0.0879)\end{array}$ & $\begin{array}{c}-0.161^{* * *} \\
(0.0573)\end{array}$ & $\begin{array}{l}-0.179 * * \\
(0.0873)\end{array}$ & $\begin{array}{c}-0.168^{* * *} \\
(0.0572)\end{array}$ & $\begin{array}{l}-0.154^{*} \\
(0.0905)\end{array}$ & $\begin{array}{l}-0.151^{* *} \\
(0.0597)\end{array}$ & $\begin{array}{l}-0.156^{*} \\
(0.0889)\end{array}$ & $\begin{array}{c}-0.153^{* * *} \\
(0.0575)\end{array}$ \\
\hline event $_{\text {trimester } 2}$ & $\begin{array}{l}-0.0323 \\
(0.0774)\end{array}$ & $\begin{array}{c}-0.0104 \\
(0.0673)\end{array}$ & $\begin{array}{l}-0.0378 \\
(0.0763)\end{array}$ & $\begin{array}{l}-0.0108 \\
(0.0635)\end{array}$ & $\begin{array}{r}-0.00119 \\
(0.0779)\end{array}$ & $\begin{array}{l}0.00464 \\
(0.0668)\end{array}$ & $\begin{array}{l}-0.0419 \\
(0.0800)\end{array}$ & $\begin{array}{c}-0.00919 \\
(0.0697)\end{array}$ \\
\hline event $_{\text {trimester } 3}$ & $\begin{array}{c}0.126 \\
(0.0929)\end{array}$ & $\begin{array}{c}0.0791 \\
(0.0808)\end{array}$ & $\begin{array}{c}0.123 \\
(0.0920)\end{array}$ & $\begin{array}{c}0.0750 \\
(0.0761)\end{array}$ & $\begin{array}{l}0.184^{* *} \\
(0.0904)\end{array}$ & $\begin{array}{c}0.107 \\
(0.0761)\end{array}$ & $\begin{array}{c}0.147 \\
(0.0928)\end{array}$ & $\begin{array}{c}0.0932 \\
(0.0835)\end{array}$ \\
\hline frequencytrimester 1 & & & $\begin{array}{c}0.00129 \\
(0.00543)\end{array}$ & $\begin{array}{c}0.00225 \\
(0.00356)\end{array}$ & & & & \\
\hline frequency ${ }_{\text {trimester } 2}$ & & & $\begin{array}{l}0.000867 \\
(0.00569)\end{array}$ & $\begin{array}{l}-0.00173 \\
(0.00394)\end{array}$ & & & & \\
\hline frequencytrimester 3 & & & $\begin{array}{r}-0.000866 \\
(0.00332)\end{array}$ & $\begin{array}{l}0.000599 \\
(0.00426)\end{array}$ & & & & \\
\hline event $_{\text {pre-pregnancy }}$ & & & & & $\begin{array}{c}0.000186^{* *} \\
(8.37 \mathrm{e}-05)\end{array}$ & $\begin{array}{c}8.98 \mathrm{e}-05 \\
(7.52 \mathrm{e}-05)\end{array}$ & & \\
\hline Constant & $\begin{array}{l}-0.615 \\
(0.536)\end{array}$ & $\begin{array}{l}-0.0367 \\
(0.438)\end{array}$ & $\begin{array}{l}-0.616 \\
(0.536)\end{array}$ & $\begin{array}{l}-0.0392 \\
(0.438)\end{array}$ & $\begin{array}{c}-3.956^{* *} \\
(1.612)\end{array}$ & $\begin{array}{l}-1.650 \\
(1.367)\end{array}$ & & \\
\hline Observations & 30,483 & 30,483 & 30,483 & 30,483 & 30,483 & 30,483 & 28,516 & 28,516 \\
\hline R-squared & 0.682 & 0.699 & 0.683 & 0.699 & 0.683 & 0.699 & 0.667 & 0.687 \\
\hline Fixed Effects & household & household & household & household & household & household & household & household \\
\hline Controls & yes & yes & yes & yes & yes & yes & yes & yes \\
\hline
\end{tabular}

Robust standard errors in parentheses (clustered on district level), *** $\mathrm{p}<0.01, * * \mathrm{p}<0.05, * \mathrm{p}<0.1$ Constant not reported. Control Variables include: hh size, number of women 15-49 in hh, number of children under age 5 , number of children between age 5 and 14 , sex of hh head, education of hh head, dummy for rural hh, hh owns dwelling, hh owns agricultural land, size of land held by hh, mother's and father's line number, mother's and father's education, biological mother/father alive, mother/father age, spouse is a relative, mother/father works, father has multiple wives, sex of child, dummy for twin, line number of child 
Table 11: OLS Result: Effect of direct gunshot with one casualty

\begin{tabular}{lccc|ccc} 
& \multicolumn{3}{c}{ Height for Age Z-Score } & \multicolumn{3}{c}{ Weight for Age Z-Score } \\
& $(1)$ & $(2)$ & $(3)$ & $(4)$ & $(5)$ & $(6)$ \\
\hline & & & & & & \\
event $_{\text {trimester } 1}$ & $-0.140^{* *}$ & $-0.103^{* *}$ & -0.122 & $-0.0718^{*}$ & $-0.110^{* * *}$ & $-0.141^{* *}$ \\
& $(0.0549)$ & $(0.0467)$ & $(0.0990)$ & $(0.0418)$ & $(0.0335)$ & $(0.0689)$ \\
event $_{\text {trimester } 2}$ & $-0.0981^{*}$ & -0.0717 & -0.0883 & 0.0221 & 0.0111 & -0.0294 \\
& $(0.0514)$ & $(0.0483)$ & $(0.0796)$ & $(0.0418)$ & $(0.0415)$ & $(0.0794)$ \\
event $_{\text {trimester } 3}$ & 0.0745 & $0.101^{*}$ & 0.121 & 0.0561 & 0.0403 & 0.0804 \\
& $(0.0525)$ & $(0.0567)$ & $(0.0983)$ & $(0.0486)$ & $(0.0485)$ & $(0.0907)$ \\
& & & & & & \\
Observations & 30,483 & 30,483 & 30,483 & 30,483 & 30,483 & 30,483 \\
R-squared & 0.011 & 0.061 & 0.682 & 0.008 & 0.065 & 0.698 \\
Fixed Effects & none & district & household & none & district & household \\
Controls & yes & yes & yes & yes & yes & yes \\
\hline \hline
\end{tabular}

Robust standard errors in parentheses (clustered on district level), ${ }^{* * *} \mathrm{p}<0.01,{ }^{* *} \mathrm{p}<0.05,{ }^{*} \mathrm{p}<0.1$ Constant not reported. Control Variables include: hh size, number of women 15-49 in hh, number of children under age 5 , number of children between age 5 and 14 , sex of hh head, education of hh head, dummy for rural hh, hh owns dwelling, hh owns agricultural land, size of land held by hh, mother's and father's line number, mother's and father's education, biological mother/father alive, mother/father age, spouse is a relative, mother/father works, father has multiple wives, sex of child, dummy for twin, line number of child

Table 12: Correlation among outcomes

\begin{tabular}{|c|c|c|c|c|c|c|c|c|c|c|c|c|c|c|}
\hline & & Mean & S.D. & 1 & 2 & 3 & 4 & 5 & 6 & 7 & 8 & 9 & 10 & 11 \\
\hline 1 & HAZ & -0.57 & 2.08 & & & & & & & & & & & \\
\hline 2 & WAZ & -0.26 & 1.84 & $\begin{array}{l}0.74 \\
(0.00)\end{array}$ & & & & & & & & & & \\
\hline 3 & letters & 0.29 & 0.45 & $\begin{array}{l}0.03 \\
(0.00)\end{array}$ & $\begin{array}{l}0.05 \\
(0.00)\end{array}$ & & & & & & & & & \\
\hline 4 & words & 0.12 & 0.32 & $\begin{array}{l}0.02 \\
(0.01)\end{array}$ & $\begin{array}{l}0.05 \\
(0.00)\end{array}$ & $\begin{array}{l}0.39 \\
(0.00)\end{array}$ & & & & & & & & \\
\hline 5 & numbers & 0.21 & 0.41 & $\begin{array}{l}0.05 \\
(0.00)\end{array}$ & $\begin{array}{l}0.06 \\
(0.00)\end{array}$ & $\begin{array}{l}0.31 \\
(0.00)\end{array}$ & $\begin{array}{l}0.34 \\
(0.00)\end{array}$ & & & & & & & \\
\hline 6 & objects & 0.90 & 0.30 & $\begin{array}{l}0.01 \\
(0.14)\end{array}$ & $\begin{array}{l}-0.00 \\
(0.87)\end{array}$ & $\begin{array}{l}0.06 \\
(0.00)\end{array}$ & $\begin{array}{l}0.07 \\
(0.00)\end{array}$ & $\begin{array}{l}0.10 \\
(0.00)\end{array}$ & & & & & & \\
\hline 7 & sick & 0.54 & 0.50 & $\begin{array}{l}0.01 \\
(0.42)\end{array}$ & $\begin{array}{l}0.01 \\
(0.30)\end{array}$ & $\begin{array}{l}0.03 \\
(0.00)\end{array}$ & $\begin{array}{l}0.01 \\
(0.25)\end{array}$ & $\begin{array}{l}-0.05 \\
(0.00)\end{array}$ & $\begin{array}{l}0.08 \\
(0.00)\end{array}$ & & & & & \\
\hline 8 & directions & 0.82 & 0.39 & $\begin{array}{l}0.00 \\
(0.74)\end{array}$ & $\begin{array}{l}0.01 \\
(0.54)\end{array}$ & $\begin{array}{l}0.12 \\
(0.00)\end{array}$ & $\begin{array}{l}0.07 \\
(0.00)\end{array}$ & $\begin{array}{l}0.11 \\
(0.00)\end{array}$ & $\begin{array}{l}0.17 \\
(0.00)\end{array}$ & $\begin{array}{l}0.05 \\
(0.00)\end{array}$ & & & & \\
\hline 9 & indep & 0.74 & 0.44 & $\begin{array}{l}0.01 \\
(0.56)\end{array}$ & $\begin{array}{l}-0.01 \\
(0.46)\end{array}$ & $\begin{array}{l}0.11 \\
(0.00)\end{array}$ & $\begin{array}{l}0.07 \\
(0.00)\end{array}$ & $\begin{array}{l}0.11 \\
(0.00)\end{array}$ & $\begin{array}{l}0.17 \\
(0.00)\end{array}$ & $\begin{array}{l}0.01 \\
(0.52)\end{array}$ & $\begin{array}{l}0.43 \\
(0.00)\end{array}$ & & & \\
\hline 10 & children & 0.84 & 0.37 & $\begin{array}{l}0.01 \\
(0.47)\end{array}$ & $\begin{array}{l}0.02 \\
(0.01)\end{array}$ & $\begin{array}{l}0.06 \\
(0.00)\end{array}$ & $\begin{array}{l}0.03 \\
(0.00)\end{array}$ & $\begin{array}{l}0.07 \\
(0.00)\end{array}$ & $\begin{array}{l}0.10 \\
(0.00)\end{array}$ & $\begin{array}{l}-0.00 \\
(0.60)\end{array}$ & $\begin{array}{l}0.17 \\
(0.00)\end{array}$ & $\begin{array}{l}0.13 \\
(0.00)\end{array}$ & & \\
\hline 11 & kicks & 0.26 & 0.44 & $\begin{array}{l}-0.02 \\
(0.01)\end{array}$ & $\begin{array}{l}-0.02 \\
(0.01)\end{array}$ & $\begin{array}{l}-0.05 \\
(0.00)\end{array}$ & $\begin{array}{l}0.00 \\
(0.59)\end{array}$ & $\begin{array}{l}-0.04 \\
(0.00)\end{array}$ & $\begin{array}{l}-0.03 \\
(0.00)\end{array}$ & $\begin{array}{l}0.07 \\
(0.00)\end{array}$ & $\begin{array}{l}-0.10 \\
(0.00)\end{array}$ & $\begin{array}{l}-0.07 \\
(0.00)\end{array}$ & $\begin{array}{l}-0.43 \\
(0.00)\end{array}$ & \\
\hline 12 & distract & 0.44 & 0.50 & $\begin{array}{l}0.00 \\
(0.96)\end{array}$ & $\begin{array}{l}-0.01 \\
(0.23)\end{array}$ & $\begin{array}{l}0.01 \\
(0.10)\end{array}$ & $\begin{array}{l}0.02 \\
(0.07)\end{array}$ & $\begin{array}{l}-0.04 \\
(0.00)\end{array}$ & $\begin{array}{l}-0.04 \\
(0.00)\end{array}$ & $\begin{array}{l}0.14 \\
(0.00)\end{array}$ & $\begin{array}{l}-0.03 \\
(0.00)\end{array}$ & $\begin{array}{l}-0.04 \\
(0.00)\end{array}$ & $\begin{array}{l}-0.06 \\
(0.00)\end{array}$ & $\begin{array}{l}0.12 \\
(0.00) \\
\end{array}$ \\
\hline
\end{tabular}

Significance levels in brackets. HAZ = Height for age z-score NCHS; WAZ = Weight for age z-score NCHS; letters = Child identifies at least ten letters of the alphabet; words = Child reads at least four simple, popular words; numbers = Child knows name and recognizes symbol of all numbers from 1-10; objects $=$ Child able to pick up small object with 2 fingers; sick $=$ Child sometimes too sick to play; directions $=$ Child follows simple directions; indep $=$ Child able to do something independently; children $=$ Child gets along well with other children; kicks $=$ Child kicks, bites or hits other children or adults; distract $=$ Child gets distracted easily 
Table 13: Conditional Logistic Regression: Effect of any Event in Trimester on Cognitive Skills, Motor Skills, and Behavioral Outcomes (Low Casualty Incidences)

\begin{tabular}{|c|c|c|c|c|c|}
\hline Panel A & $\begin{array}{c}(1) \\
\text { letters }\end{array}$ & $\begin{array}{c}(2) \\
\text { words }\end{array}$ & $\begin{array}{c}(3) \\
\text { numbers }\end{array}$ & $\begin{array}{c}(4) \\
\text { objects }\end{array}$ & $\begin{array}{l}(5) \\
\text { sick }\end{array}$ \\
\hline event $_{\text {trimester } 1}$ & $\begin{array}{l}1.310 \\
(0.468)\end{array}$ & $\begin{array}{l}0.324^{*} \\
(0.213)\end{array}$ & $\begin{array}{c}0.704 \\
(0.297)\end{array}$ & $\begin{array}{c}0.512 \\
(0.248)\end{array}$ & $\begin{array}{c}1.078 \\
(0.252)\end{array}$ \\
\hline event $_{\text {trimester } 2}$ & $\begin{array}{c}0.202^{a} \\
(0.0922)\end{array}$ & $\begin{array}{c}0.244^{* *} \\
(0.173)\end{array}$ & $\begin{array}{c}1.117 \\
(0.420)\end{array}$ & $\begin{array}{c}0.754 \\
(0.274)\end{array}$ & $\begin{array}{c}0.806 \\
(0.213)\end{array}$ \\
\hline event $_{\text {trimester } 3}$ & $\begin{array}{c}0.758 \\
(0.278)\end{array}$ & $\begin{array}{c}0.485 \\
(0.261)\end{array}$ & $\begin{array}{l}1.208 \\
(0.430)\end{array}$ & $\begin{array}{l}0.511^{*} \\
(0.195)\end{array}$ & $\begin{array}{c}1.360 \\
(0.301)\end{array}$ \\
\hline No. of HHs & 505 & 333 & 509 & 375 & 760 \\
\hline Panel B & directions & indep & children & kicks & distract \\
\hline event $_{\text {trimester } 1}$ & $\begin{array}{c}0.678 \\
(0.191)\end{array}$ & $\begin{array}{l}0.434^{a} \\
(0.111)\end{array}$ & $\begin{array}{c}1.310 \\
(0.463)\end{array}$ & $\begin{array}{c}1.136 \\
(0.264)\end{array}$ & $\begin{array}{c}0.512^{* *} \\
(0.147)\end{array}$ \\
\hline event $_{\text {trimester } 2}$ & $\begin{array}{c}0.918 \\
(0.222)\end{array}$ & $\begin{array}{c}0.707 \\
(0.210)\end{array}$ & $\begin{array}{l}0.515^{a} \\
(0.132)\end{array}$ & $\begin{array}{l}1.075 \\
(0.301)\end{array}$ & $\begin{array}{c}0.993 \\
(0.307)\end{array}$ \\
\hline event $_{\text {trimester } 3}$ & $\begin{array}{c}0.733 \\
(0.228)\end{array}$ & $\begin{array}{l}0.493^{*} \\
(0.180)\end{array}$ & $\begin{array}{c}0.735 \\
(0.266)\end{array}$ & $\begin{array}{c}1.394 \\
(0.392)\end{array}$ & $\begin{array}{c}0.778 \\
(0.234)\end{array}$ \\
\hline No. of HHs & 613 & 759 & 590 & 836 & 755 \\
\hline $\begin{array}{l}\text { Fixed Effects } \\
\text { Controls }\end{array}$ & $\begin{array}{c}\text { household } \\
\text { yes }\end{array}$ & $\begin{array}{c}\text { household } \\
\text { yes }\end{array}$ & $\begin{array}{c}\text { household } \\
\text { yes }\end{array}$ & $\begin{array}{c}\text { household } \\
\text { yes }\end{array}$ & $\begin{array}{c}\text { household } \\
\text { yes }\end{array}$ \\
\hline
\end{tabular}

Odds Ratios reported. Robust standard errors in parentheses (clustered on district level), a $\mathrm{p}<0.01$ and significant with Bonferroni adjustment, ${ }^{*} \mathrm{p}<0.05,{ }^{*} \mathrm{p}<0.1$ Constant not reported. Control Variables include: hh size, number of women 15-49 in hh, number of children under age 5 , number of children between age 5 and 14 , sex of hh head, education of hh head, dummy for rural hh, hh owns dwelling, hh owns agricultural land, size of land held by hh, mother's and father's line number, mother's and father's education, biological mother/father alive, mother/father age, spouse is a relative, mother/father works, father has multiple wives, sex of child, dummy for twin, line number of child 
Table 14: OLS Results: Perpetrator of Violence

\begin{tabular}{|c|c|c|c|c|c|c|c|c|}
\hline & \multicolumn{2}{|c|}{ Low Casualty } & \multicolumn{2}{|c|}{ Bombs \& Explosions } & \multicolumn{2}{|c|}{ Homogeneous Dist. } & \multicolumn{2}{|c|}{ Polarized Dist. } \\
\hline Perpetrator & $\begin{array}{l}\text { Height } \\
(1) \\
\end{array}$ & $\begin{array}{c}\text { Weight } \\
(2)\end{array}$ & $\begin{array}{c}\text { Height } \\
(3) \\
\end{array}$ & $\begin{array}{c}\text { Weight } \\
(4) \\
\end{array}$ & $\begin{array}{c}\text { Height } \\
(5)\end{array}$ & $\begin{array}{c}\text { Weight } \\
(6) \\
\end{array}$ & $\begin{array}{c}\text { Height } \\
(7) \\
\end{array}$ & $\begin{array}{c}\text { Weight } \\
(8)\end{array}$ \\
\hline Coalition & $\begin{array}{l}-0.0114 \\
(0.0473)\end{array}$ & $\begin{array}{l}-0.0411 \\
(0.0431)\end{array}$ & $\begin{array}{l}0.0639 \\
(0.159)\end{array}$ & $\begin{array}{c}0.157 \\
(0.156)\end{array}$ & $\begin{array}{l}-0.0355 \\
(0.0454)\end{array}$ & $\begin{array}{l}-0.0532 \\
(0.0371)\end{array}$ & $\begin{array}{c}-0.00256 \\
(0.175)\end{array}$ & $\begin{array}{l}0.0710 \\
(0.211)\end{array}$ \\
\hline Insurgent & $\begin{array}{c}0.00551 \\
(0.0580)\end{array}$ & $\begin{array}{c}0.0358 \\
(0.0429)\end{array}$ & $\begin{array}{c}0.0613 \\
(0.0561)\end{array}$ & $\begin{array}{c}0.0442 \\
(0.0388)\end{array}$ & $\begin{array}{c}0.0243 \\
(0.0561)\end{array}$ & $\begin{array}{c}0.0373 \\
(0.0441)\end{array}$ & $\begin{array}{c}0.439 \\
(0.348)\end{array}$ & $\begin{array}{c}0.218 \\
(0.191)\end{array}$ \\
\hline Sectarian & $\begin{array}{c}-0.118^{* * *} \\
(0.0362)\end{array}$ & $\begin{array}{c}-0.0919 * * * \\
(0.0343)\end{array}$ & $\begin{array}{l}-0.113^{*} \\
(0.0660)\end{array}$ & $\begin{array}{l}-0.0964 * \\
(0.0523)\end{array}$ & $\begin{array}{c}-0.147^{* * *} \\
(0.0405)\end{array}$ & $\begin{array}{c}-0.0967 * * \\
(0.0400)\end{array}$ & $\begin{array}{l}-0.274 \\
(0.246)\end{array}$ & $\begin{array}{l}-0.260 \\
(0.205)\end{array}$ \\
\hline Observations & 30,483 & 30,483 & 30,483 & 30,483 & 24,755 & 24,755 & 3,130 & 3,130 \\
\hline $\begin{array}{l}\text { R-squared } \\
\text { Fixed Effects } \\
\text { Controls }\end{array}$ & $\begin{array}{c}0.061 \\
\text { district } \\
\text { ves }\end{array}$ & $\begin{array}{c}0.068 \\
\text { district } \\
\text { ves }\end{array}$ & $\begin{array}{c}0.061 \\
\text { district } \\
\text { yes }\end{array}$ & $\begin{array}{c}0.068 \\
\text { district } \\
\text { yes }\end{array}$ & $\begin{array}{c}0.056 \\
\text { district } \\
\text { yes }\end{array}$ & $\begin{array}{c}0.072 \\
\text { district } \\
\text { ves }\end{array}$ & $\begin{array}{c}0.089 \\
\text { district } \\
\text { yes }\end{array}$ & $\begin{array}{c}0.080 \\
\text { district } \\
\text { ves }\end{array}$ \\
\hline
\end{tabular}

Robust standard errors in parentheses (clustered on district level), *** $\mathrm{p}<0.01,{ }^{*} \mathrm{p}<0.05,{ }^{*} \mathrm{p}<0.1$ Constant not reported. Observations restricted to low casualty incidences (1-4 deaths) and only incidences with a unique perpetrator. Control Variables include: hh size, number of women 15-49 in hh, number of children under age 5 , number of children between age 5 and 14 , sex of hh head, education of hh head, dummy for rural hh, hh owns dwelling, hh owns agricultural land, size of land held by hh, mother's and father's line number, mother's and father's education, biological mother/father alive, mother/father age , spouse is a relative, mother/father works, father has multiple wives, sex of child, dummy for twin, line number of child

Table 15: Correlation between Perpetrator and Severity of Attack

\begin{tabular}{lccc}
\hline & Coalition & Insurgent & Sectarian \\
\hline \multirow{2}{*}{ Duration (Days) } & 0.0090 & -0.0110 & 0.0054 \\
& 0.2205 & 0.1347 & 0.4629 \\
& & & \\
Casualties & $0.0609^{* * *}$ & 0.0043 & $-0.0284^{* * *}$ \\
& 0.0000 & 0.5597 & 0.0001 \\
\hline
\end{tabular}

Table 15 shows pairwise correlation between perpetrator and severity of incident, measured as the duration in days and the number of casualties. P-values are reported under the correlation coefficients. 
Table 16: Heterogeneity across district characteristics

\begin{tabular}{|c|c|c|c|c|c|c|}
\hline & $\begin{array}{c}(1) \\
\text { HAZ }\end{array}$ & $\begin{array}{c}(2) \\
\text { WAZ }\end{array}$ & $\begin{array}{c}(3) \\
\text { HAZ }\end{array}$ & $\begin{array}{c}(4) \\
\text { WAZ }\end{array}$ & $\begin{array}{c}(5) \\
\text { HAZ }\end{array}$ & $\begin{array}{c}(6) \\
\text { WAZ }\end{array}$ \\
\hline event & $\begin{array}{c}-0.245^{* *} \\
(0.112)\end{array}$ & $\begin{array}{c}-0.186^{*} \\
(0.103)\end{array}$ & $\begin{array}{l}-0.245 \\
(0.160)\end{array}$ & $\begin{array}{l}-0.202 \\
(0.136)\end{array}$ & $\begin{array}{c}0.100 \\
(0.233)\end{array}$ & $\begin{array}{l}0.0309 \\
(0.210)\end{array}$ \\
\hline event*unemployment & $\begin{array}{c}0.963 \\
(1.314)\end{array}$ & $\begin{array}{c}0.367 \\
(0.933)\end{array}$ & & & & \\
\hline event*rural population & & & $\begin{array}{c}0.161 \\
(0.339)\end{array}$ & $\begin{array}{l}0.0937 \\
(0.275)\end{array}$ & & \\
\hline event*public good instability & & & & & $\begin{array}{l}-0.0352 \\
(0.0273)\end{array}$ & $\begin{array}{l}-0.0247 \\
(0.0259)\end{array}$ \\
\hline Constant & $\begin{array}{l}-0.441 \\
(0.529)\end{array}$ & $\begin{array}{l}-0.0784 \\
(0.417)\end{array}$ & $\begin{array}{l}-0.443 \\
(0.531)\end{array}$ & $\begin{array}{l}-0.0791 \\
(0.417)\end{array}$ & $\begin{array}{l}-0.437 \\
(0.530)\end{array}$ & $\begin{array}{c}-0.0745 \\
(0.416)\end{array}$ \\
\hline Observations & 26,603 & 26,603 & 26,603 & 26,603 & 26,603 & 26,603 \\
\hline R-squared & 0.687 & 0.703 & 0.687 & 0.703 & 0.687 & 0.703 \\
\hline Fixed Effects & household & household & household & household & household & household \\
\hline Controls & yes & yes & yes & yes & yes & yes \\
\hline
\end{tabular}


Table 17: Correlation between Control Variables and Main Outcomes

\begin{tabular}{|c|c|c|c|c|c|c|}
\hline & $\begin{array}{l}(1) \\
\text { sick }\end{array}$ & $\begin{array}{c}(2) \\
\text { directions }\end{array}$ & $\begin{array}{c}\quad(3) \\
\text { indep }\end{array}$ & $\begin{array}{c}(4) \\
\text { children }\end{array}$ & $\begin{array}{c}(5) \\
\text { kicks }\end{array}$ & $\begin{array}{c}(6) \\
\text { distract }\end{array}$ \\
\hline \multicolumn{7}{|l|}{ Household } \\
\hline hhsize & $\begin{array}{l}-0.0219^{*} \\
(0.0119)\end{array}$ & $\begin{array}{c}0.00268 \\
(0.00979)\end{array}$ & $\begin{array}{c}0.0233 \\
(0.0280)\end{array}$ & $\begin{array}{c}0.0120 \\
(0.0327)\end{array}$ & $\begin{array}{c}0.0576^{* *} \\
(0.0272)\end{array}$ & $\begin{array}{l}0.00782 \\
(0.0358)\end{array}$ \\
\hline hhwm & $\begin{array}{c}0.0246 \\
(0.0198)\end{array}$ & $\begin{array}{l}-0.00815 \\
(0.0188)\end{array}$ & $\begin{array}{l}-0.0421 \\
(0.0387)\end{array}$ & $\begin{array}{l}0.00729 \\
(0.0448)\end{array}$ & $\begin{array}{l}-0.0733 \\
(0.0473)\end{array}$ & $\begin{array}{l}-0.0605 \\
(0.0540)\end{array}$ \\
\hline hhch5 & $\begin{array}{l}-0.0237 \\
(0.0144)\end{array}$ & $\begin{array}{l}-0.0200 \\
(0.0135)\end{array}$ & $\begin{array}{l}0.00741 \\
(0.0409)\end{array}$ & $\begin{array}{l}0.0118 \\
(0.0482)\end{array}$ & $\begin{array}{l}-0.0555 \\
(0.0427)\end{array}$ & $\begin{array}{l}-0.0177 \\
(0.0477)\end{array}$ \\
\hline hhan & $\begin{array}{c}0.110^{* * *} \\
(0.0410)\end{array}$ & $\begin{array}{c}0.0700 \\
(0.0446)\end{array}$ & $\begin{array}{c}-0.333^{* * *} \\
(0.112)\end{array}$ & $\begin{array}{c}-0.357^{* *} \\
(0.160)\end{array}$ & $\begin{array}{c}-0.395^{* * *} \\
(0.0957)\end{array}$ & $\begin{array}{c}-0.252^{* *} \\
(0.119)\end{array}$ \\
\hline hhch14 & $\begin{array}{c}-0.0432^{* * *} \\
(0.0116)\end{array}$ & $\begin{array}{c}-0.0512^{* * *} \\
(0.0117)\end{array}$ & $\begin{array}{c}0.0151 \\
(0.0284)\end{array}$ & $\begin{array}{c}0.0223 \\
(0.0296)\end{array}$ & $\begin{array}{l}-0.0447 \\
(0.0283)\end{array}$ & $\begin{array}{l}-0.00652 \\
(0.0351)\end{array}$ \\
\hline hhfem & $\begin{array}{l}-0.139^{*} \\
(0.0795)\end{array}$ & $\begin{array}{l}-0.0368 \\
(0.0669)\end{array}$ & $\begin{array}{l}0.0369 \\
(0.131)\end{array}$ & $\begin{array}{c}0.252 \\
(0.185)\end{array}$ & $\begin{array}{l}0.0640 \\
(0.161)\end{array}$ & $\begin{array}{l}-0.139 \\
(0.170)\end{array}$ \\
\hline helevel & $\begin{array}{l}-0.0421 \\
(0.0337)\end{array}$ & $\begin{array}{l}-0.00101 \\
(0.0284)\end{array}$ & $\begin{array}{c}0.0159 \\
(0.0538)\end{array}$ & $\begin{array}{c}0.115 \\
(0.0859)\end{array}$ & $\begin{array}{c}0.143^{* * *} \\
(0.0531)\end{array}$ & $\begin{array}{c}0.0445 \\
(0.0900)\end{array}$ \\
\hline rural & $\begin{array}{c}-0.186^{* * *} \\
(0.0544)\end{array}$ & $\begin{array}{l}-0.105^{* *} \\
(0.0474)\end{array}$ & $\begin{array}{l}-0.0746 \\
(0.120)\end{array}$ & $\begin{array}{c}-0.382^{* *} \\
(0.163)\end{array}$ & $\begin{array}{c}-0.301^{* * *} \\
(0.110)\end{array}$ & $\begin{array}{l}0.0946 \\
(0.157)\end{array}$ \\
\hline hhown & $\begin{array}{c}0.0134 \\
(0.0449)\end{array}$ & $\begin{array}{l}-0.0337 \\
(0.0518)\end{array}$ & $\begin{array}{c}0.0458 \\
(0.0978)\end{array}$ & $\begin{array}{l}0.0729 \\
(0.110)\end{array}$ & $\begin{array}{l}-0.0160 \\
(0.0919)\end{array}$ & $\begin{array}{c}0.134 \\
(0.167)\end{array}$ \\
\hline hhland & $\begin{array}{c}0.0822 \\
(0.0651)\end{array}$ & $\begin{array}{l}-0.0344 \\
(0.0589)\end{array}$ & $\begin{array}{c}0.119 \\
(0.120)\end{array}$ & $\begin{array}{c}0.170 \\
(0.117)\end{array}$ & $\begin{array}{c}0.235 \\
(0.162)\end{array}$ & $\begin{array}{l}0.0307 \\
(0.146)\end{array}$ \\
\hline hhls & $\begin{array}{r}-0.000402 \\
(0.00125)\end{array}$ & $\begin{array}{l}0.00215^{*} \\
(0.00129)\end{array}$ & $\begin{array}{l}-0.00221 \\
(0.00359)\end{array}$ & $\begin{array}{c}-0.0117^{* * *} \\
(0.00366)\end{array}$ & $\begin{array}{c}-0.00979^{*} \\
(0.00558)\end{array}$ & $\begin{array}{c}0.00420 \\
(0.00375)\end{array}$ \\
\hline \multicolumn{7}{|l|}{ Parents } \\
\hline mline & $\begin{array}{c}0.00759 \\
(0.0111)\end{array}$ & $\begin{array}{l}-0.0178^{*} \\
(0.00992)\end{array}$ & $\begin{array}{c}0.0213 \\
(0.0262)\end{array}$ & $\begin{array}{l}0.00450 \\
(0.0310)\end{array}$ & $\begin{array}{c}0.0404 \\
(0.0256)\end{array}$ & $\begin{array}{l}-0.0158 \\
(0.0296)\end{array}$ \\
\hline fline & $\begin{array}{c}-0.000863 \\
(0.0108)\end{array}$ & $\begin{array}{l}0.0235^{* *} \\
(0.00985)\end{array}$ & $\begin{array}{c}0.0369 \\
(0.0322)\end{array}$ & $\begin{array}{c}0.0438 \\
(0.0385)\end{array}$ & $\begin{array}{c}0.0411 \\
(0.0273)\end{array}$ & $\begin{array}{l}-0.00597 \\
(0.0257)\end{array}$ \\
\hline felevel & $\begin{array}{c}0.110^{* * *} \\
(0.0356)\end{array}$ & $\begin{array}{c}0.0429 \\
(0.0290)\end{array}$ & $\begin{array}{c}0.109 \\
(0.0704)\end{array}$ & $\begin{array}{l}0.0235 \\
(0.0774)\end{array}$ & $\begin{array}{c}0.0703 \\
(0.0619)\end{array}$ & $\begin{array}{l}-0.0304 \\
(0.110)\end{array}$ \\
\hline melevel & $\begin{array}{l}0.0499^{*} \\
(0.0269)\end{array}$ & $\begin{array}{c}0.0463^{* *} \\
(0.0223)\end{array}$ & $\begin{array}{l}0.147^{* *} \\
(0.0638)\end{array}$ & $\begin{array}{c}0.144^{*} \\
(0.0752)\end{array}$ & $\begin{array}{c}0.381^{* * *} \\
(0.0500)\end{array}$ & $\begin{array}{l}-0.0294 \\
(0.0890)\end{array}$ \\
\hline mage & $\begin{array}{l}-4.12 \mathrm{e}-05 \\
(0.00275)\end{array}$ & $\begin{array}{l}-0.00157 \\
(0.00287)\end{array}$ & $\begin{array}{c}0.00531 \\
(0.00544)\end{array}$ & $\begin{array}{l}0.0164^{* *} \\
(0.00697)\end{array}$ & $\begin{array}{l}0.0139 * * \\
(0.00649)\end{array}$ & $\begin{array}{c}-0.0175^{* *} \\
(0.00868)\end{array}$ \\
\hline fage & $\begin{array}{c}0.00294 \\
(0.00258)\end{array}$ & $\begin{array}{c}0.00317 \\
(0.00240)\end{array}$ & $\begin{array}{l}0.0163^{* * *} \\
(0.00394)\end{array}$ & $\begin{array}{l}0.00929^{*} \\
(0.00547)\end{array}$ & $\begin{array}{c}0.0166^{* * *} \\
(0.00447)\end{array}$ & $\begin{array}{c}0.0208^{* * *} \\
(0.00573)\end{array}$ \\
\hline relative & $\begin{array}{c}-0.0616^{*} \\
(0.0318)\end{array}$ & $\begin{array}{l}-0.0111 \\
(0.0299)\end{array}$ & $\begin{array}{l}-0.0413 \\
(0.0544)\end{array}$ & $\begin{array}{l}-0.0760 \\
(0.0786)\end{array}$ & $\begin{array}{c}0.0332 \\
(0.0590)\end{array}$ & $\begin{array}{c}0.0637 \\
(0.0861)\end{array}$ \\
\hline mwork & $\begin{array}{c}0.0214 \\
(0.0505)\end{array}$ & $\begin{array}{l}0.0530 \\
(0.0458)\end{array}$ & $\begin{array}{l}0.302^{* *} \\
(0.141)\end{array}$ & $\begin{array}{l}0.0661 \\
(0.114)\end{array}$ & $\begin{array}{c}0.0155 \\
(0.0969)\end{array}$ & $\begin{array}{l}0.355^{* *} \\
(0.154)\end{array}$ \\
\hline wives & $\begin{array}{l}-0.0809 \\
(0.0516)\end{array}$ & $\begin{array}{l}-0.00546 \\
(0.0493)\end{array}$ & $\begin{array}{l}-0.135 \\
(0.122)\end{array}$ & $\begin{array}{l}0.0468 \\
(0.139)\end{array}$ & $\begin{array}{l}-0.198 \\
(0.131)\end{array}$ & $\begin{array}{l}0.0286 \\
(0.140)\end{array}$ \\
\hline Child & & & & & & \\
\hline female & $\begin{array}{c}0.112^{* * *} \\
(0.0278)\end{array}$ & $\begin{array}{c}0.0804^{* * *} \\
(0.0224)\end{array}$ & $\begin{array}{c}0.0534 \\
(0.0413)\end{array}$ & $\begin{array}{c}0.0540 \\
(0.0666)\end{array}$ & $\begin{array}{c}0.0859 \\
(0.0528)\end{array}$ & $\begin{array}{c}0.0836 \\
(0.0540)\end{array}$ \\
\hline twin & $\begin{array}{c}-0.00407 \\
(0.103)\end{array}$ & $\begin{array}{l}-0.0762 \\
(0.0927)\end{array}$ & $\begin{array}{l}-0.224 \\
(0.184)\end{array}$ & $\begin{array}{l}-0.277 \\
(0.259)\end{array}$ & $\begin{array}{l}-0.147 \\
(0.220)\end{array}$ & $\begin{array}{l}0.0623 \\
(0.219)\end{array}$ \\
\hline LN & $\begin{array}{c}0.0140 \\
(0.0113)\end{array}$ & $\begin{array}{c}0.0158 \\
(0.0112)\end{array}$ & $\begin{array}{l}-0.0386 \\
(0.0271)\end{array}$ & $\begin{array}{l}-0.0430 \\
(0.0412)\end{array}$ & $\begin{array}{c}-0.0851^{* * *} \\
(0.0272)\end{array}$ & $\begin{array}{c}-0.000519 \\
(0.0332)\end{array}$ \\
\hline $\begin{array}{l}\text { Observations } \\
\text { R-squared }\end{array}$ & $\begin{array}{c}30,483 \\
0.010\end{array}$ & 30,483 & 12,200 & 12,214 & 12,208 & 12,124 \\
\hline
\end{tabular}

Table shows conditional correlation between all controls and main outcome variables. Robust standard errors in parentheses (clustered on district level), ${ }^{* *} \mathrm{p}<0.01,{ }^{* *} \mathrm{p}<0.05,{ }^{*} \mathrm{p}<0.1$ Constant not reported. Control Variables include: hh size, number of women 15-49 in hh, number of children under age 5 , number of children between age 5 and 14, sex of hh head, education of hh head, dummy for rural hh, hh owns dwelling, hh owns agricultural land, size of land held by hh, mother's and father's line number, mother's and father's education, biological mother/father alive, mother/father age, spouse is a relative, mother/father works, father has multiple wives, sex of child, dummy for twin, line number of child. Interaction components are controlled for separately. Outcome variables are described in 2 . 
Table 18: Correlation between Control Variables and Main Outcomes

\begin{tabular}{|c|c|c|c|c|c|c|}
\hline & $\begin{array}{l}(1) \\
\text { sick }\end{array}$ & $\begin{array}{c}(2) \\
\text { directions }\end{array}$ & $\begin{array}{c}(3) \\
\text { indep }\end{array}$ & $\begin{array}{c}(4) \\
\text { children }\end{array}$ & $\begin{array}{c}(5) \\
\text { kicks }\end{array}$ & $\begin{array}{c}(6) \\
\text { distract }\end{array}$ \\
\hline \multicolumn{7}{|l|}{ Household } \\
\hline hhsize & $\begin{array}{c}-0.00714 \\
(0.0193)\end{array}$ & $\begin{array}{c}0.0344 \\
(0.0252)\end{array}$ & $\begin{array}{l}0.00392 \\
(0.0204)\end{array}$ & $\begin{array}{c}0.0145 \\
(0.0227)\end{array}$ & $\begin{array}{c}0.0159 \\
(0.0214)\end{array}$ & $\begin{array}{r}-0.00649 \\
(0.0229)\end{array}$ \\
\hline hhwm & $\begin{array}{l}-0.00770 \\
(0.0327)\end{array}$ & $\begin{array}{l}-0.0212 \\
(0.0446)\end{array}$ & $\begin{array}{l}-0.0270 \\
(0.0377)\end{array}$ & $\begin{array}{c}-0.0906^{* *} \\
(0.0443)\end{array}$ & $\begin{array}{l}-0.0140 \\
(0.0396)\end{array}$ & $\begin{array}{l}0.00210 \\
(0.0362)\end{array}$ \\
\hline hhch5 & $\begin{array}{l}-0.0171 \\
(0.0294)\end{array}$ & $\begin{array}{c}-0.0728^{* *} \\
(0.0370)\end{array}$ & $\begin{array}{l}-0.0366 \\
(0.0350)\end{array}$ & $\begin{array}{l}-0.0417 \\
(0.0391)\end{array}$ & $\begin{array}{c}0.0679^{* *} \\
(0.0314)\end{array}$ & $\begin{array}{c}0.0421 \\
(0.0315)\end{array}$ \\
\hline hhan & $\begin{array}{c}0.0602 \\
(0.0816)\end{array}$ & $\begin{array}{c}-0.186^{* *} \\
(0.0894)\end{array}$ & $\begin{array}{l}-0.0878 \\
(0.0803)\end{array}$ & $\begin{array}{c}-0.249^{* * *} \\
(0.0793)\end{array}$ & $\begin{array}{c}0.110^{*} \\
(0.0582)\end{array}$ & $\begin{array}{c}0.174^{*} \\
(0.0893)\end{array}$ \\
\hline hhch14 & $\begin{array}{l}-0.0347^{*} \\
(0.0197)\end{array}$ & $\begin{array}{l}-0.0143 \\
(0.0273)\end{array}$ & $\begin{array}{r}-0.00208 \\
(0.0227)\end{array}$ & $\begin{array}{l}-0.0175 \\
(0.0273)\end{array}$ & $\begin{array}{l}-0.0193 \\
(0.0228)\end{array}$ & $\begin{array}{c}0.0160 \\
(0.0209)\end{array}$ \\
\hline hhfem & $\begin{array}{c}-0.00455 \\
(0.121)\end{array}$ & $\begin{array}{c}-0.00625 \\
(0.157)\end{array}$ & $\begin{array}{l}-0.105 \\
(0.127)\end{array}$ & $\begin{array}{c}-0.0533 \\
(0.166)\end{array}$ & $\begin{array}{c}-0.0454 \\
(0.135)\end{array}$ & $\begin{array}{l}0.0738 \\
(0.149)\end{array}$ \\
\hline helevel & $\begin{array}{c}-0.000112 \\
(0.0507)\end{array}$ & $\begin{array}{l}0.0978^{*} \\
(0.0520)\end{array}$ & $\begin{array}{c}0.0973^{*} \\
(0.0510)\end{array}$ & $\begin{array}{c}0.0956 \\
(0.0587)\end{array}$ & $\begin{array}{c}0.0149 \\
(0.0557)\end{array}$ & $\begin{array}{c}0.0147 \\
(0.0527)\end{array}$ \\
\hline rural & $\begin{array}{l}0.00637 \\
(0.0934)\end{array}$ & $\begin{array}{c}-0.00958 \\
(0.116)\end{array}$ & $\begin{array}{l}-0.0480 \\
(0.101)\end{array}$ & $\begin{array}{c}0.146 \\
(0.0964)\end{array}$ & $\begin{array}{c}0.0216 \\
(0.0851)\end{array}$ & $\begin{array}{c}-0.141 \\
(0.0983)\end{array}$ \\
\hline hhown & $\begin{array}{l}-0.0391 \\
(0.0936)\end{array}$ & $\begin{array}{c}0.0131 \\
(0.0930)\end{array}$ & $\begin{array}{l}-0.0422 \\
(0.0897)\end{array}$ & $\begin{array}{c}0.0493 \\
(0.0883)\end{array}$ & $\begin{array}{l}-0.0322 \\
(0.0772)\end{array}$ & $\begin{array}{l}-0.0831 \\
(0.0980)\end{array}$ \\
\hline hhland & $\begin{array}{c}0.00121 \\
(0.106)\end{array}$ & $\begin{array}{c}-0.00734 \\
(0.111)\end{array}$ & $\begin{array}{l}0.0202 \\
(0.104)\end{array}$ & $\begin{array}{c}0.00240 \\
(0.113)\end{array}$ & $\begin{array}{c}-0.113 \\
(0.0796)\end{array}$ & $\begin{array}{l}-0.0741 \\
(0.102)\end{array}$ \\
\hline hhls & $\begin{array}{c}0.00283 \\
(0.00251) \\
\end{array}$ & $\begin{array}{c}0.0117^{* * *} \\
(0.00331) \\
\end{array}$ & $\begin{array}{c}0.00299 \\
(0.00266) \\
\end{array}$ & $\begin{array}{c}0.00151 \\
(0.00346) \\
\end{array}$ & $\begin{array}{c}0.00157 \\
(0.00201) \\
\end{array}$ & $\begin{array}{l}-0.00149 \\
(0.00337) \\
\end{array}$ \\
\hline \multicolumn{7}{|l|}{ Parents } \\
\hline mline & $\begin{array}{c}-0.00139 \\
(0.0230)\end{array}$ & $\begin{array}{c}-0.00710 \\
(0.0190)\end{array}$ & $\begin{array}{c}-0.0102 \\
(0.0202)\end{array}$ & $\begin{array}{c}0.0116 \\
(0.0267)\end{array}$ & $\begin{array}{l}-0.00789 \\
(0.0239)\end{array}$ & $\begin{array}{c}-0.00824 \\
(0.0244)\end{array}$ \\
\hline fline & $\begin{array}{c}0.0242 \\
(0.0242)\end{array}$ & $\begin{array}{l}-0.0152 \\
(0.0222)\end{array}$ & $\begin{array}{c}-0.00409 \\
(0.0234)\end{array}$ & $\begin{array}{c}0.0116 \\
(0.0237)\end{array}$ & $\begin{array}{l}-0.0106 \\
(0.0168)\end{array}$ & $\begin{array}{l}0.00670 \\
(0.0258)\end{array}$ \\
\hline felevel & $\begin{array}{c}-0.0851^{*} \\
(0.0500)\end{array}$ & $\begin{array}{c}0.0158 \\
(0.0695)\end{array}$ & $\begin{array}{c}0.0260 \\
(0.0586)\end{array}$ & $\begin{array}{l}0.00622 \\
(0.0666)\end{array}$ & $\begin{array}{l}-0.0501 \\
(0.0527)\end{array}$ & $\begin{array}{l}-0.0111 \\
(0.0540)\end{array}$ \\
\hline melevel & $\begin{array}{l}-0.0556 \\
(0.0508)\end{array}$ & $\begin{array}{c}0.0829 \\
(0.0597)\end{array}$ & $\begin{array}{c}0.0321 \\
(0.0531)\end{array}$ & $\begin{array}{r}-0.00829 \\
(0.0561)\end{array}$ & $\begin{array}{c}0.0269 \\
(0.0435)\end{array}$ & $\begin{array}{r}-0.0929^{* *} \\
(0.0467)\end{array}$ \\
\hline mage & $\begin{array}{c}-0.00246 \\
(0.00541)\end{array}$ & $\begin{array}{c}0.00262 \\
(0.00699)\end{array}$ & $\begin{array}{l}-0.00172 \\
(0.00506)\end{array}$ & $\begin{array}{l}0.0125^{* *} \\
(0.00597)\end{array}$ & $\begin{array}{l}-0.00193 \\
(0.00565)\end{array}$ & $\begin{array}{l}-0.00576 \\
(0.00524)\end{array}$ \\
\hline fage & $\begin{array}{c}0.00219 \\
(0.00375)\end{array}$ & $\begin{array}{c}0.00150 \\
(0.00493)\end{array}$ & $\begin{array}{l}0.00768^{*} \\
(0.00392)\end{array}$ & $\begin{array}{c}0.00459 \\
(0.00569)\end{array}$ & $\begin{array}{l}-0.00326 \\
(0.00469)\end{array}$ & $\begin{array}{c}0.00259 \\
(0.00430)\end{array}$ \\
\hline relative & $\begin{array}{c}0.0679 \\
(0.0487)\end{array}$ & $\begin{array}{c}0.0882 \\
(0.0613)\end{array}$ & $\begin{array}{l}-0.0455 \\
(0.0628)\end{array}$ & $\begin{array}{l}-0.0602 \\
(0.0571)\end{array}$ & $\begin{array}{c}0.0497 \\
(0.0471)\end{array}$ & $\begin{array}{c}0.176^{* * *} \\
(0.0492)\end{array}$ \\
\hline mwork & $\begin{array}{c}0.176^{*} \\
(0.0967)\end{array}$ & $\begin{array}{c}0.313^{* * *} \\
(0.119)\end{array}$ & $\begin{array}{c}0.108 \\
(0.113)\end{array}$ & $\begin{array}{c}0.00294 \\
(0.143)\end{array}$ & $\begin{array}{c}-0.0538 \\
(0.112)\end{array}$ & $\begin{array}{l}0.0590 \\
(0.136)\end{array}$ \\
\hline wives & $\begin{array}{r}-0.0178 \\
(0.118) \\
\end{array}$ & $\begin{array}{l}0.0199 \\
(0.114)\end{array}$ & $\begin{array}{c}-0.190^{*} \\
(0.111)\end{array}$ & $\begin{array}{c}-0.204^{*} \\
(0.119)\end{array}$ & $\begin{array}{c}0.270^{* * *} \\
(0.0850)\end{array}$ & $\begin{array}{c}0.0487 \\
(0.0996) \\
\end{array}$ \\
\hline Child & & & & & & \\
\hline female & $\begin{array}{l}-0.0150 \\
(0.0357)\end{array}$ & $\begin{array}{c}0.205^{* * *} \\
(0.0596)\end{array}$ & $\begin{array}{l}0.0899^{*} \\
(0.0492)\end{array}$ & $\begin{array}{c}0.445^{* * *} \\
(0.0582)\end{array}$ & $\begin{array}{c}-0.543^{* * *} \\
(0.0560)\end{array}$ & $\begin{array}{l}-0.0430 \\
(0.0425)\end{array}$ \\
\hline twin & $\begin{array}{c}0.144 \\
(0.155)\end{array}$ & $\begin{array}{l}-0.113 \\
(0.201)\end{array}$ & $\begin{array}{l}0.0915 \\
(0.181)\end{array}$ & $\begin{array}{c}-0.00454 \\
(0.167)\end{array}$ & $\begin{array}{c}-0.0103 \\
(0.157)\end{array}$ & $\begin{array}{c}-0.387^{* *} \\
(0.164)\end{array}$ \\
\hline LN & $\begin{array}{l}0.00556 \\
(0.0235)\end{array}$ & $\begin{array}{l}-0.0227 \\
(0.0233)\end{array}$ & $\begin{array}{c}-0.00503 \\
(0.0191)\end{array}$ & $\begin{array}{c}-0.00524 \\
(0.0270)\end{array}$ & $\begin{array}{c}0.0148 \\
(0.0241)\end{array}$ & $\begin{array}{c}0.0157 \\
(0.0241)\end{array}$ \\
\hline Observations & 12,173 & 12,152 & 12,128 & 12,218 & 12,210 & 11,795 \\
\hline
\end{tabular}

Table shows conditional correlation between all controls and main outcome variables. Robust standard errors in parentheses (clustered on district level), ${ }^{* * *} \mathrm{p}<0.01,{ }^{* *} \mathrm{p}<0.05,{ }^{*} \mathrm{p}<0.1$ Constant not reported. Control Variables include: hh size, number of women 15-49 in hh, number of children under age 5, number of children between age 5 and 14 , sex of hh head, education of hh head, dummy for rural hh, hh owns dwelling, hh owns agricultural land, size of land held by hh, mother's and father's line number, mother's and father's education, biological mother/father alive, mother/father age, spouse is a relative, mother/father works, father has multiple wives, sex of child, dummy for twin, line number of child. Interaction components are controlled for separately. Outcome variables are described in 2 . 